\title{
From Masterly Brokers to Compliant Protégées: The Frontier Governance System and the Rise of Ethnic Confrontation in China-Inner Mongolia, $1900-1930^{1}$
}

\author{
Liping Wang \\ University of Chicago
}

\begin{abstract}
Center-periphery explanations focus on political centralization, state collapse, and nationalization to explain the genesis of separatist movements that form new national states. This study shows that three periods of Chinese-Mongolian relations - land reform (1900-1911), revolution and interregnum(1912-16) and warlordism(1917-30) — contained events that center-periphery perspectives associate with the rise of autonomous movements, yet Mongolian separatism did not occur until the last period. To explain this puzzle, the author characterizes the formation, integration, and dismemberment of the frontier governance system as an intermediate body between the center and the periphery. She demonstrates that the effects pointed to by center-periphery explanations were mediated, at least in the case of Inner Mongolia, by the structural transformations of the frontier governance system. Not assuming a natural opposition between the center and the periphery, this study elucidates the polarization of the center-periphery relationship and its impact on minority separatism.
\end{abstract}

This article explains the timing of Mongolian separatism within the context of Chinese imperial dissolution in the early 20th century. Mongols were the most powerful and important minority allies of the Qing Empire (1644-

${ }^{1}$ The author wishes to thank Julia Adams, Sida Liu, Peter Perdue, Geng Tian, Xiaohong $\mathrm{Xu}$, Nick Wilson, and Dingxin Zhao for their helpful comments on early drafts of this article. She also thanks Mark Gould for his helpful comments on the final revision and the

(C) 2015 by The University of Chicago. All rights reserved.

0002-9602/2015/12006-0002\$10.00

AJS Volume 120 Number 6 (May 2015): 1641-89

1641 
1912). Their political status was severely jeopardized by the late Qing land reform launched around 1905, as well as by the substitution of Manchu (the ruling minority of the Qing Empire) rule by a Han Chinese republic after the 1911 revolution. In center-periphery explanations, political centralization, state collapse, and nationalization are key events that trigger minority separatism in imperial settings. Yet none of these events directly triggered Mongolian separatism. Instead, Mongolian separatism emerged almost one decade after the dissolution of the Qing Empire, at a moment when Chinese provincial warlordism prevailed. In this article, I attempt to explain why.

In terms of the scale of territory, ethnic diversity, and imperial organization, the Qing Empire resembled the Ottoman and Tsarist Russian Empires to a high degree. After encountering western modernization in the 19th century, all three empires underwent dramatic transformations, and, to various degrees, all were haunted by the peril of imperial dissolution. After all, imperial crisis was often precipitated by minorities' various endeavors to readjust their positions in the imperial structure, coalescing into a fissuring force that broke apart the empires. Among these three empires, the politicization of minority identity occurred latest in China, with Mongols being the first minority group to expressly articulate ethnic separatism. I contend that the belated emergence of minority separatism in China can be successfully explained only by taking into account China's unique structure of frontier governance.

The frontier governance system examined in this article designates an intermediate body of governance that linked the frontier to the imperial court and bridged interaction between Mongols and Han Chinese. It was not a pure agent of the imperial center, even though it greatly facilitated central state expansion on many occasions. Neither did it naturally merge with any particular indigenous ethnic groups, even though their collaborations were frequent. In Inner Mongolia, the frontier governance system was a multiethnic organization, incorporating Manchu military governors who led Manchu garrisons, Mongolian banner nobles who were the hereditary leaders of the basic Mongolian units (the banners), and Han Chinese migrant elites who administratively responded to the commands of neighboring Han Chinese provincial governors. The frontier governance system mediated interactions between center and periphery, Han and Mongols, while simultaneously fortifying its own autonomy. The transformations of its structure-from a relatively loose assemblage of multiethnic actors to a highly integrated brokerage system - and its final dismemberment help us better understand the mysterious timing of Mongolian separatism in China.

AJS reviewers for their feedback, which made a significant improvement possible. The author is of course responsible for any errors. Direct correspondence to Liping Wang, Social Sciences Collegiate Division, University of Chicago, 5845 South Ellis Avenue, Chicago, Illinois 60637. E-mail: lipingw@uchicago.edu 
Theoretically, my study discusses the merits and limitations of centerperiphery explanations that underlie the majority of scholarship on empireto-nation transition. These explanations view a set of events (including political centralization, nationalization, and state collapse) as the cause of minority nationalism within the imperial context. By envisioning the periphery as either safely secluded from the imperial center via a mode of indirect rule or directly controlled by the center in transition toward direct rule, these explanations offer a parsimonious, yet crude, model of imperial organization. My study pinpoints the existence of the frontier governance system as an intermediate body of governance that leads to the rejection of a simplified categorization of direct or indirect rule. A characterization of the nature and transformation of the frontier governance system enables us to specify under what conditions political centralization, nationalization, and state collapse reinforce or dilute ethnic tensions and when they lead to separatist movements. My study therefore will enrich discussions of center-periphery relationship by adding qualifications.

The article is organized into five parts. The first part outlines centerperiphery explanations, their insights on the organization, operation, and dissolution of empires, and my alternative approach to these questions. The second part introduces the historical background of the China-Inner Mongolia case and the primary data used to support my argument. The next three parts analyze the transformations of the frontier governance system, with a special focus on the change in recruitment and role of the frontier military governors. In conclusion, I briefly discuss the implications of this study for more general comparative research on empires and nationalism.

\section{EMPIRE, THE CENTER-PERIPHERY MODEL, AND MINORITY NATIONALISM}

The dissolution of empires is often considered a consequence of minority ethnic mobilizations. These mobilizations can be oriented toward nationalism if they call for "making the boundary of the nation coterminous with that of the state" (Hechter 2000, p. 7). In such cases, mobilizations involve secessionist movements toward establishing independent sovereign states. They can also involve struggles for specific ethnic rights, while not ostensibly seeking political independence. The causal connections between minority ethnic mobilizations and imperial dissolution are illustrated by many studies. ${ }^{2}$ Despite disparate historical narratives, many of these studies focus

\footnotetext{
${ }^{2}$ For minority separatism in Tsarist Russia and the Soviet Union, see Suny (1993), Brubaker (1994), Beissinger (2002), Martin (2001), and Hirsch (2005). For the Ottoman case, see Davison (1977), Haddad (1977), Breuilly (1982), Keyder (1997), Wimmer (2002), Barkey (2006, 2008). For ethnicity and European colonialism, see Young (1965), Mamdani (1996), Cooper (1997), Posner (2005).
} 
on a center-periphery relationship. The dynamic interactions between the imperial center and the periphery are often conceived as determined by a set of key events - that is, political centralization, state collapse, and nationalization - which in effect increase or decrease the attachment of the peripheral minorities. That consequently leads to the maintenance or dissolution of the empire.

\section{Center-Periphery Explanations}

Center-periphery explanations, in various versions, underscore the notion that an empire is structurally and functionally distinct from a nation-state. Most empire studies endorse such a view. Being wary of the shortcomings of the nation-state framework (Go 2009; Adams and Steinmetz 2015), many contemporary scholars tend to emphasize two correlated aspects of empire: its decentralized structure and its capacity to contain ethnic conflicts. ${ }^{3}$

The decentralized structure makes empire characteristically an assemblage of territories whose populations rarely intermingle and whose communication with the center is poor. Retaining the ultimate symbolic authority in the center, most empires allow indigenous political leaders to run their own affairs (Tilly 1997; Hechter 2000, p. 27). Using the example of the 18th-century Ottoman Empire, Karen Barkey (1994) shows that political decentralization was more a sign of strength than weakness in the empire, as it allowed the imperial rulers to fully adapt to local needs. ${ }^{4}$

Scholars of colonialism use another term, "indirect rule," to indicate the decentralized structure of empires. Indirect rule was a British innovation of the 19th century designed to solve the problems brought about by the expansion of colonialism that challenged earlier forms of rule that featured civilizing missions and cultural assimilation. ${ }^{5}$ The quintessential tenet of "indirect rule," as illustrated by Lord Lugard (1965), is that by coopting lo-

\footnotetext{
${ }^{3}$ Some scholars dispute the dichotomy between empire and nation-state. For example, Krishan Kumar (2010, pp. 124-28) argues that the often idealized European nation-states were not internally unified, thus making them undistinguishable from the old empires. Also see David Armitage's (2000) discussion of the composite monarchies and Robert Bartlett's (1993) work on the internal conquests within Europe.

${ }^{4}$ Barkey (1994) and a few others (such as Salzmann 1993) argue that the empowerment of local militia and the privatization of the state administration do not imply the "decline" of the Ottoman Empire in this period. Rather, from 1695 to 1793, decentralization generated large, diffuse, but interrelated loci of state power, which helped convey state authority into local dominions, thus "laying the social foundation for the centralizing polities instituted from 1812 on."

${ }^{5}$ According to Frederick Cooper (1997, p. 410), early colonial regimes at times took the reformist agenda seriously. By the 1920s, however, both Great Britain and France gradually displaced their civilizing missions with nominal "indirect rule" in order to preserve "customary" tribal authority.
} 
cal rulers into the system of imperial authority, the empire could be ruled cheaply and conveniently (Mamdani 1996).

Following these discussions, many scholars attempt, by focusing on the center-periphery relationship, to explain how empires could successfully contain nationalism. Michael Hechter's work offers a good example. He suggests that indirect rule designates a decentralized structure in which authority is divided between a center and the constituted lower-level units (e.g., provinces, states, regions, and localities; Hechter 2000, p. 27). These lower-level units are likely to be culturally heterogeneous, and it is important to realize that they tend to be homogeneous within their boundaries (Hechter 2000, p. 43). Such a structure allows local authorities, coming from multiethnic backgrounds, to evade arbitrary interventions and coercions from the center and thus be responsible for their own governance. The lack of interlocal communications further increases the costs of any horizontal mobilizations. This structure consequently reduces the chances of contact between different ethnic populations (Hechter et al. 2006). It also reduces the possibility of group comparison, a key mechanism leading to ethnic conflict (Horowitz 1985, p. 165).

Yet, despite the advantages of indirect rule, it could not eliminate imperial crises elicited by some dramatic events that threatened to break apart the center-periphery relationship. In fact, the relatively autonomous local governance provided organizational resources for peripheral separatist movements. A decaying central state losing the capacity to maintain social control (Tilly 1997; Hechter 2000, pp. 33-34) often generated opportunities for peripheral separatism, which was launched to readdress grievances and readjust the distribution of group interests (Davison 1977; Khalidi 1977; Haddad 1977; Campbell 2007). Exogenous shocks such as world war or domestic liberal reforms could also be catalytic events to tip the center-periphery balance. For example, Ellen Comisso (2006) elucidates how World War I procured opportunities for minority separatism in the Habsburg and Ottoman empires, a situation exacerbated by the intervention of the Great Powers. In a different light, Mark Beissinger (2002) depicts how a swift liberal turn in the former Soviet Union engendered a series of "contentious events" that unfolded between the all-union government and the contending minority leaders, facilitating the reconfiguration of minority identities in ways that demanded political separation.

Among the dramatic events compelling minority separatism, the most important one is the shift of empire from indirect to direct rule (Doyle 1986; Hechter 2000; Wimmer 2002; Barkey 2008), often embodied in the form of state nationalism (Anderson 1983, chap. 6). Direct rule increased state penetration at the expense of local political autonomy. By imposing the dominant culture on local minorities, it also severely affected the cultural autonomy of the indigenous people. As a result, minority separatism occurred. 
These studies elucidate the evolving dynamics between the center and the periphery. They show that empire was vulnerable in the face of some dramatic events, including political centralization, nationalization, state collapse, and the intervention of foreign powers, which strained the centerperiphery relationship. These events are often claimed as the causes of minority separatism. Historical literature on minority separatism in the Ottoman and Russian Empires attest to such an explanation.

\section{Minority Separatism in the Ottoman and Russian Empires}

The demise of the Ottoman Empire is conventionally considered to be an outcome of burgeoning minority separatism within its multiple peripheries beginning in the 19th century. Among the multiple frontiers, the HellenistBalkan region receives the most attention and provides much of our knowledge about ethnic problems in the Ottoman Empire. ${ }^{6}$ The intensive nation building embarked upon by the Ottoman Empire starting in the mid-19th century is thought to have adversely strained the relationship between the central state and local minority groups, resulting in the centrifugal movements that eventually shattered the empire.

The Ottoman rulers conquered west Anatolia, Bulgaria, northern Greece, Bosnia, and Serbia and secured the subordination of the Christian princes in southwest Europe around the 13th and 14th centuries (Shaw 1976-77, p. 12). Their eastern march, concluded in the 16th century, was accomplished by war with the Safavids, the conquest of eastern Anatolia, and the eventual subjugation of the Arab world. Yet, from the mid-17th through the 18th centuries, Ottoman rule became increasingly decentralized, especially in the Balkan region. The impetus behind such a change, as Barkey (2008, p. 241) suggests, was the flourishing of international trade, which turned the Balkans into a commercial center where both Christian and Jewish merchants established extensive business kinship networks through their family members in European cities. When the sultan instituted the Tanzimat reform in the mid-19th century in order to recentralize state control in its various domains, resistance movements toward autonomy-often clothed in ethnic/national slogans - quickly erupted and engulfed the whole Balkan region.

Although scholars use different names to describe the traditional decentralized Ottoman rule (e.g., indirect rule, Hechter [2000]; mosaic structure, Wimmer [2002]; brokerage system, Barkey [2008]), they all agree that political decentralization preempted peripheral separatism in Ottoman history. The Tanzimat reform - intended to empower the state in confronta-

${ }^{6}$ For how minorities in the "western frontier" first initiated nationalist movements to challenge the control of the Ottoman imperial center, see Davison (1977), Haddad (1977), Breuilly (1982), Keyder (1997), Barkey (2008). 
tions with the European powers - signified the transition of the empire to a nation-state. By introducing parliamentary institutions and education reforms, the central state endangered the status quo of peripheral minority elites and their cultural autonomy (Wimmer 2002, p. 166). These events aroused peripheral separatism.

The demise of the Tsarist Russian Empire provides another case, one where minority separatism merged with a proletarian social revolution to generate violent and sweeping repercussions permeating and reaching beyond the Russian Empire (Lenin [1914] 1995; Slezkine 1994; Von Hagen 1997; Martin 2001, chap. 2; Riga 2008). The Tsarist reform initiated after 1905 tightened state control in many realms. Short of upward mobility, the middle and upper-middle classes of various minority groups (in particular the Jews, Poles, Germans, and other advanced minorities) feared the intrusion of the Russian state as much as did the Russian proletariat, whose lives were impoverished by aggressive state taxation. ${ }^{7}$ As with the Ottoman Empire, the Russian turn toward intensive nation-state building deeply aggravated the peripheral minorities. Quite differently, the minorities' discontent was further incited by the Russian Bolsheviks, who understood the power of an all-encompassing revolution that merged ethnic and proletarian revolutions.

Although the Russian story fits quite well with the center-periphery model, it should be noted that the Romanov Russian Empire was for centuries a polyglot and polyreligious state, which cleaved along both religious and nonethnic differences, instead of being compartmentalized into clearly defined national units (Brubaker 1994, n. 12). The configuration of centerperiphery relationship best matches the case of the Soviet Union rather than that of the Russian Empire. A nested model of center-periphery interactions is used by Brubaker (1994) to explain the rise of minority separatism in the Soviet Union.

Embodying the principle of ethnoterritorial federalism, the Soviet Union was constructed as a set of national-territorial administrative units- the national republics - "to harness, contain, channel, and control the potentially disruptive political expression of nationality" (Brubaker 1994, p. 49). To substantiate the political boundary of national republics, the Soviet leaders produced rigid codifications of personal nationality, cultivated national languages, cadres, and intelligentsias and pursued deliberate, affirmative nation building. The central state coordinated the organization of these titular national units, each of which represented an ethnic periphery. ${ }^{8}$ When

${ }^{7}$ For the common fate of the minority elite and the Russian proletariat, see Riga (2008, 2012).

${ }^{8}$ Hardening the national/ethnic boundary and making it coterminous with the territorialadministrative boundary of each republic is an innovation created by the collective efforts of Soviet politicians and ethnographers; see Suny (1993), Martin (2001). 
Soviet liberal reform, initiated in the late 1980s, slackened central state control and unbalanced jurisdictional struggles between the center and the periphery, the first layer of the center-periphery relationship dissolved. Subsequently an enormous wave of peripheral separatism exploded. ${ }^{9}$

More than that, Brubaker sagaciously points out that within each titular nation, a second layer of center-periphery relationships also deteriorated. Each national republic was founded in accordance with the law of ethnoterritorial federalism. Smaller communities of subminorities were endowed with cultural autonomy by the central government. These marginal ethnocultural communities contested the hegemony of titular nations and aggravated tensions between them following the independence of those nations.

In other words, the Soviet Union was split by two levels of spreading center-periphery conflicts: one unfolding between the central government and national republics, the other between the titular nations and marginal cultural minorities. The nested model complicates the baseline model of the center-periphery relationship, as it acknowledges that the periphery was not homogeneous, but was fractured by plural ethnic groups. In the Soviet case, the sudden relaxation of central state control, not political centralization, became a catalyst of minority separatism. Despite these major differences, the nested model is still focused on the events that strained the interactions between a presumably bounded center and a bounded periphery.

To briefly summarize, all these studies concentrate on the center-periphery relationship to illustrate the correlation between the eruption of minority nationalism and imperial downfall. They assume that empire is composed of an imperial center with multiple peripheries and that the latter are at best only loosely coupled with the former, in accordance to the rule of decentralization. As a result, the peripheral political elites enjoy high autonomy, because the decentralized political structure reduces the central impact, as well as the contact, among ethnically different subjects in the imperial realm. Owing to this structure, many empires have successfully contained peripheral centrifugal movements.

Events leading to peripheral separatism vary. There can be a sudden collapse of the imperial center, due to the devastation of a violent revolution. There can also be a formation of independent nonstate economic ties that facilitates the horizontal connections among the peripheral peoples. This can be seen in the case of the Ottoman-Balkan region. A sudden softening of

\footnotetext{
${ }^{9}$ Motyl (2001) similarly emphasizes that the disintegration of the USSR starts from the dysfunctional bureaucracy in the center, which compelled peripheral autonomy. Beissinger (2002, pp. 26-27) also argues that the political environment caused by "loosened state authority" after the liberal reform provided an opportunity structure for the mobilization of peripheral separatism. Seeing the inability of the center to launch repressive countermeasures, peripheral minorities grasped this opportunity to challenge the Soviet identity laid down by the center.
} 
state authority, as in the case of the Soviet Union, can be another catalyst for peripheral separation. Most important, the stimulus can be the shift from indirect to direct rule, implemented to increase state power and empire-wide cultural homogenization. These events all contribute to the rearrangement of center-periphery relationship. If painstaking bargaining processes fail to pacify both sides, this failure, too, triggers peripheral separatism movements. This model has proven its strength in the cases of the Ottoman Empire, the Soviet Union, and, partially, Tsarist Russia. Can it provide an equally robust explanation to the causes and timing of peripheral separatism in the China case?

The main focus in this study is on the Inner Mongolian frontier during the late Qing Empire and the early Republic of China, circa the 1890s to 1930s. This period can be broken into three phases: land reform (19001911), revolution (1912-16), and warlordism (1917-30). Both the first and third phase saw intensive political centralization, one implemented by the Qing court and the other by the provincial warlords' regimes. Mongolian separatism did not erupt until the third phase rather than the first one. The second phase saw the collapse of the imperial center with simultaneous attempts to sinicize frontier institutions. During that period, the Mongolian frontier remained peaceful and did not see large-scale separatism. The belated emergence of Mongolian separatism within the context of Chinese imperial dissolution suggests that we need to search for a new explanation.

This new explanation will recognize the unique structure of the Chinese empire - characterized by the frontier governance system as an intermediate body - that buffered center-periphery and Mongol-Han relationships in China. Its rise and fall significantly confounds the impact of state centralization, revolution, state collapse, and nationalization. Clarifying the structural transformations of this system will help us better understand when these dramatic events have a causal effect on minority separatist movements.

\section{THE UNIQUE STRUCTURE OF THE CHINESE IMPERIAL SYSTEM}

Inner Mongolia is a high, sunny, windy plateau that gradually slopes down to the Gobi Desert separating Inner Mongolia from Mongolia proper. The annual rainfall on the steppe is less than 14 inches, and its small rivers flowing north into the Gobi soon disappear in the sand and grass. Irrigation in this land is not practical, which makes it ideal for herding (Atwood 2002, pp. 56-59). Mongols, or more broadly the nomads, their advance or retreat, their growth or decline, decisively influenced patterns of expansion and contraction of the Chinese empire. This uncertainty of frontier boundary gradually disappeared after the Manchu conquest in 1644; at that time Inner Mongolia was stabilized as an internal frontier of China (Lattimore 1940; Perdue 2005). 
Unlike the principalities in the Balkan region or Eastern Europe, Inner Mongolia did not form any supralocal political center dominated by a sovereign-like ruler. Rather, the mobile Mongols were scattered in small, isolated units whose political association rarely exceeded the confines of clans and tribes. Adapting to the indigenous segmentation of the Mongols, the Qing Empire instituted a complex governance system to harness their mobility while bestowing upon them a relative autonomy. These measures distinguished Mongols from the majority Han Chinese, who were subject to regular bureaucratic control.

In the Qing Empire, the realm of Inner Mongolia was divided into four eastern (Jerim, Josotu, Juu Uda, and Shili-yin Gool leagues) and two western leagues (Ulaanchab and Yekhe Juu leagues). ${ }^{10}$ Its boundaries were much smaller than the contemporary Inner Mongolian Autonomous Region under the People's Republic of China, because it did not include the northeastern section inhabited by the Hulun Buir Solon Eight Banners and the New Bargu Eight Banners. Nor did it include the western part that extends into Gansu and Ningxia provinces where the Oriot Mongols lived (see fig. 1).

In this large space, the Qing emperors heavily relied on the cooperation among the Mongolian leagues and banners, the Manchu military governors, and the neighboring Han Chinese provinces. Figure 2 illustrates the Inner Mongolian governance structure under the Qing.

Figure 2 shows that the basic unit of Mongolian governance is the banner/league institution. With the exception of the Eight Banners of Chakhar and the Tümed Banners in Guihua town, which were governed by nonhereditary officials directly appointed by the emperor, most parts of Inner Mongolia were divided into banners and leagues that recognized the leadership of the jasag nobles. Each Mongol banner, khoshuu in Mongolian, was a decimal organization that combined civilian and military functions. It usually contained about 3,000-8,000 members in the high steppe and 15,000-25,000 people near China (Atwood 2002, p. 24). ${ }^{11}$ The banner was divided into several sum (literally, "arrows") and each sum or arrow was

\footnotetext{
${ }^{10}$ The Chakhar Banners, Tümed Banners, and four special grazing lands (si muchang) Shangdu, Mingan, Zuoyi, and Youyi-scattered in this region were often called "Internal Mongolia" (neishu menggu) to distinguish them from "Inner Mongolia" (Tan 1935, pp. 34-37). Although Justin Tighe translates the neishu menggu as "Court Mongolia," I literally translate it as "Internal Mongolia." In Internal Mongolia, Mongols were not ruled by hereditary jasag nobles but by imperial appointees. The autonomy of the inhabitants of this region was more circumscribed than was the case for Inner Mongolia (Tighe 2005, p. 39). A banner was the basic military and civilian organization of Mongols under the Qing. On the banner institution, see a summary account by Brunnert et al. (1911) or Aberle and Vreeland (1962).

${ }^{11}$ In the decimal system, the Mongols were organized into units of tens, hundreds, and thousands.
} 


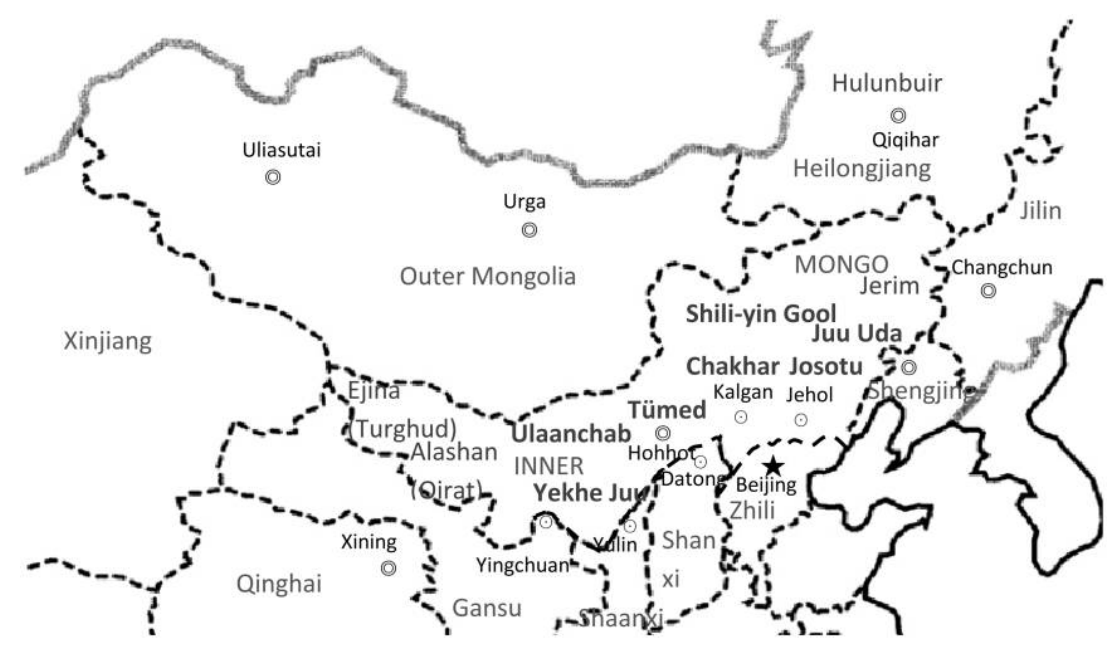

FIG. 1.-Map: Inner Mongolia under the Qing, 1644-1911 (this map is made with the assistance of Yi Wang).

requested to provide 150 adult males capable of military service. In addition to its military function, the banner was also "the hereditary domain of the ruling lord who managed its subjects and territory with the assistance of a series of officials and held judicial authority over his subjects" (Boldbaatar and Sneath 2006, p. 299). In other words, the banner leaders were also in charge of the civil and judicial administration of the Mongols.

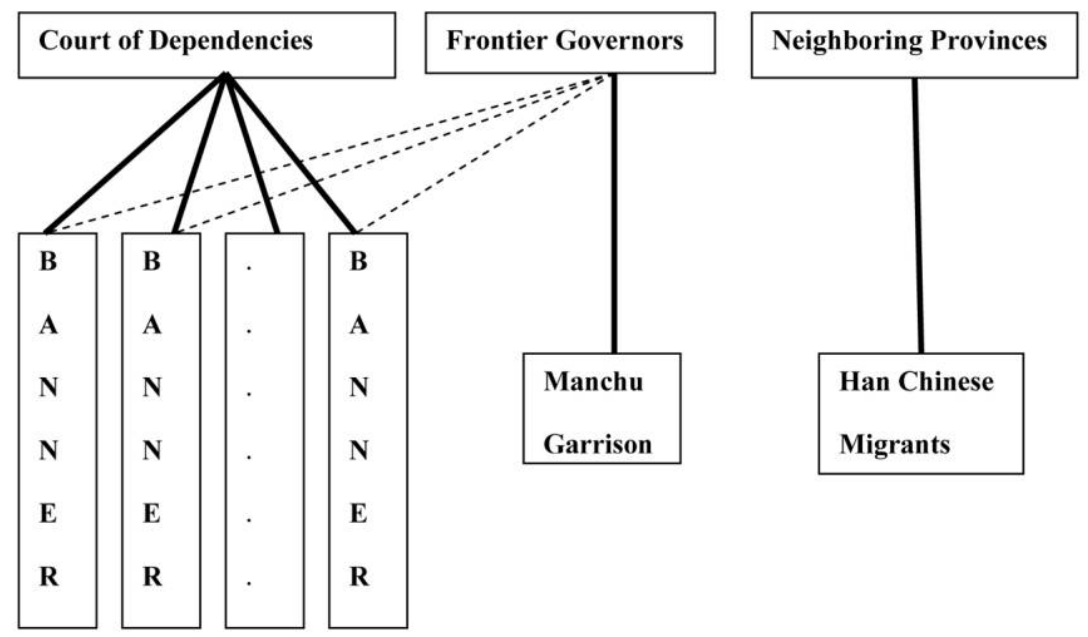

FIG. 2.-Inner Mongolian Governance Structure under the Qing, 1644-1900 
To counter the free mobility of the Mongols, lest a powerful leader like Genghis Khan arise, the Manchu emperors fixed the domains of the banners. Under the Qing, Inner Mongolia was divided into 49 banners. The jasag, normally a descendent of the Borjigin family (the Golden lineage descended from Genghis Khan), was selected from among and elected by the banner nobles. Usually there existed six ranks of nobles within the banner. Above the banner, Manchu rulers set up the league as a temporary organization for the banner leaders to make decisions on important interbanner affairs. ${ }^{12}$

The banner-league institution allowed Mongol elites to manage their internal affairs autonomously. It appears to be the equivalent of indirect rule in China. Yet its autonomy was constrained by other governing institutions. First of all, banners were subordinate to Lifan yuan (the Court of Dependencies), a central institution that managed frontier affairs and the regular relationship with tributary states. They were also under the occasional inspection of frontier military governors, who were dispatched to maintain frontier military security. ${ }^{13}$ Among the frontier military governors, the three roles most important in Inner Mongolia were Suiyuan jiangjun (general), Chakhar dutong (commander-in-chief), and Jehol dutong. ${ }^{14}$

The autonomy of Mongol banners was further restricted by the extended oversight of the neighboring Han Chinese provincial authorities. Inner Mongolia geographically abutted the territory of several northern Chinese provinces. Poor Han Chinese peasants, peddlers, fugitives, and disbanded soldiers often crossed the Great Wall and infiltrated the frontier. This migration resulted in the penetration of the Chinese provincial administration. Consequently, Chinese-style local governments, specifically the ting (subprefectures), were established to govern the Han Chinese migrants residing in the frontier region. ${ }^{15}$

\footnotetext{
${ }^{12}$ For more details, see Su-de-bi-li-ge (2007, pp. 8-9). Su-de-bi-li-ge points out that not all Mongols were organized into this banner-league system. The Internal Mongols were not assigned the jasag as their leaders. Instead, the nonhereditary officials Zongguan or fu Zongguan directly governed them; these officials could be removed at the discretion of the Manchu emperor. Internal Mongols included those intimate to the Manchu court and the rebellious ones, who were carefully placed under direct control of the Manchu court.

${ }^{13}$ For more details see Zhao (1993, pp. 338-40, 105-8) and Su-de-bi-li-ge (2007, pp. 6-7).

${ }^{14}$ Suiyuan jiangjun was appointed in 1737 . He was supposed to be responsible for military affairs related to two Tümed banners, the Ulaanchab and Yekhe Juu leagues. In 1761, Chakhar dutong was appointed at Zhangjiakou, taking care of the eight Chakhar banners and the four special grazing lands, as well as the military affairs in the Shiliyin Gool league. In 1810, Jehol dutong was appointed, taking care of the Josotu and JuuUda leagues.

${ }^{15}$ Ting (subprefecture) is a special unit of civil administration uncommon in the Chinese inner land, but popular in the frontier. According to Skinner ([1977] 1995), "While prefectures, departments and counties were most commonly found throughout China Proper, the establishment of dependent and independent sub-prefectures was a favored
} 
To summarize, under the Qing rule, Inner Mongolia was governed by multiple institutions. The autonomy of the Mongol banners was moderated by interventions from Lifan yuan, Manchu military governors, and the neighboring Han Chinese provincial governments. For most of the Qing dynasty, this governance system was only loosely coupled. Its integration was significantly improved only after land reform practices were inaugurated in the early 20 th century. This governance system uniquely characterized the Chinese empire and complicates the mechanisms and effects of center-periphery dynamics.

To portray the structural transformations of the frontier governance system, I will focus on both institutional changes and the reconstruction of leadership. I use both primary and secondary sources. In this article, the archival sources of the Department of Mongolian and Tibetan Affairs are applied in English-language scholarship for the first time. The correspondence among the frontier military governors, Han Chinese migrant elites, the central government, and the neighboring Chinese provinces manifests their complex interactions.

My second contribution is a compilation of the biographies of major frontier military governors. These data show the refashioning of the frontier collective leadership over four decades. While compiling the biographical data, I mostly referred to Qing shi lie zhuan [Biographies related to the Qing history] (Guoshiguan and Zhonghua shu ju 1928), Minguo renwu da cidian [Dictionary of the people during the Republic of China] (Xu 2007), Qingdai renwu zhuangao [Biographical drafts of the people under the Qing] (Qingshi bianwei hui 1984), privately edited nianpu (chronicles), and biographies written by scholars. In addition to these sources, I have extensively used the published memorials of the frontier military governors, local gazetteers, as well as secondary works. Relying on these sources, I will show that the rise and fall of the frontier governance system, rather than the events of political centralization, state collapse and nationalization, most appropriately explains the timing of the Mongolian separatism. ${ }^{16}$

\section{LAND REFORM AND A BROKERAGE SYSTEM UNDER THE FRONTIER MILITARY GOVERNORS, 1900-11}

Land reform was part of the New Policy Reform (xinzheng) launched by the Qing court after China's defeat in the first Sino-Japanese war (1895).

means of incorporating Inner Asian areas bordering on China Proper within the Chinese administrative system" (p. 303). The ting were governed as an extension of border provinces, but they were often directly managed by the provincial military circuits rather than being tightly organized into a subunit of provincial prefectures.

${ }^{16}$ Even though I have tried to let the Mongols speak in my narratives, currently I still lack sufficient sources to enrich their profiles and activities. I hope this defect can be rectified through future research. 
The New Policy Reform resembled the Ottoman Tanzimat reform of 1839 and the Russian Great Reform of the 1860s in terms of the goal to increase state capacity and the integration of local society. ${ }^{17}$ The Chinese name for the land reform is fangken (land reclamation) ${ }^{18}$ Its most important goal was to officially open the grazing land-hitherto exclusively reserved for the Mongols - for agrarian cultivation. Banners consenting to open their lands were required first to submit thorough land-register books to the emperor, who subsequently sent special superintendents to conduct onsite land surveys. The superintendents, often commanded by the frontier military governors, organized land cultivation bureaus in specific locations/areas and pooled Chinese land merchants and peasants who were willing to take the land. The superintendents sold licenses to cultivators who wanted to purchase cultivation rights and helped to collect land rent and taxes. All these new initiatives greatly amplified sources of state revenue. ${ }^{19}$ By criminalizing private land transactions, the superintendents also transferred an important part of Mongolian land rights to the state and allowed the state to dictate the distribution of land income and compensation paid to Mongols who had lost their land. These actions therefore indicated progress in political centralization.

Moreover, throughout the land reform process, the frontier military governors were elevated above other actors in the frontier governance system. They enlisted support from both the Mongol banners and the Han Chinese migrant elites, thus becoming the most powerful brokers in frontier land transactions. Since the frontier military governors were delegates dispatched by the court, their strengthened presence in Mongolian politics is another sign of political centralization. Why this trend of centralization did not provoke Mongolian separatism is the key question I will answer in this section.

The centralization of land rights did not result in direct state control of Mongolian affairs. Rather, this centralization process was accompanied by the consolidation of the frontier governance system as an intermediate body between the state and the frontier, Mongols and Han. Relying on the support of both Mongol banners and Han Chinese migrants, the frontier military governors greatly increased the integration of the frontier governance system. They reduced unwanted interventions from Lifan yuan and the neighboring Han Chinese provinces, and they bridged the Mongolian and Han Chinese administrations. If the prereform frontier governance

\footnotetext{
${ }^{17}$ For a general introduction to the New Policy Reform, see Ichiko (1980).

${ }^{18}$ Fangken in Chinese literally means "to open and plow new soil." I am here using the translation by Tighe (2005, p. 102).

${ }^{19}$ According to Baoyu (1985, p. 38) between 1902 and 1911 approximately 2,641,200 silver taels were collected from the Wild Land Money ( yahuang yin) and the Land Price Money (dijia yin) imposed during fangken in Suiyuan.
} 
system manifested a loosely assembled structure in which the Mongolian banners, Lifan yuan, the frontier military governors, and the expanded Han Chinese administrative units each occupied a separate functioning niche, the postreform governance system was characterized by pervasive connections among these components. This new system became a solid intermediate body, transfigured the center-periphery linkages, and greatly diffused the pressure of political centralization. The following discussion will show how this system mitigated the impact of centralization that would have increased ethnic tensions.

\section{Change of the Governance Structure}

Unlike Lifan yuan, whose interaction with the Mongols was highly codified and therefore unlikely to change, the frontier military governors' role was poorly specified. Other than guarding frontier security, their responsibilities varied according to special needs. Their thorough knowledge of frontier affairs and their ability to handle delicate situations rendered them ideal candidates to implement the land reforms. Frontier military governors performed two actions that increased the integration of the frontier governance system. One was to take control of both land cultivation bureaus and the Han Chinese subprefectures. The other was to penetrate banner affairs and reduce the connections between banners and the Lifan yuan. These measures tightly welded the interests of the Mongol banners, the Manchu military governors, and the Han Chinese migrant elites. They fortified the intermediate governing body that ultimately became an important buffering mechanism of the center-periphery relationship in late imperial China. I will use the story of Yigu, one of the most important frontier military governors, to illustrate the restructuring process.

The Manchu official Yigu was the best-known superintendent of land cultivation and the best-known military governor in Inner Mongolia. Before being appointed as Suiyuan jiangjun in 1903, Yigu demonstrated his ability to handle Mongolian affairs while serving in the position of superintendent of land cultivation. He established land cultivation bureaus in Suiyuan (duban mengqi kenwu zongju) and Fengning (Fengning kenwuju) to take care of the land affairs in the right banners of Chakhar. He also established a bureau in Zhangjiakou (Zhangjiakou kenwu zongju) to manage land affairs in the left banners of Chakhar. Moreover, he established the Western Leagues Land Cultivation Bureau for the Ulaanchab and Yekhe Juu leagues. In September 1902, Yigu set up the East and West Land Reclamation Companies in charge of the land affairs in the Chakhar, Ulaan$c h a b$, and Yekhe Juu leagues. These institutions were preserved and regularized when he moved from superintendent to Suiyuan jiangjun (for more details, see Zhao [1989, pp. 157-60] and Su-de-bi-li-ge [2005, pp. 78-79]). 
At this time, as we know, Han Chinese migrants flooded into Inner Mongolia and challenged the tenuous Han Chinese administration that was sparsely stationed in the subprefectures. Consequently, subprefectures multiplied (Tighe 2005, pp. 65). These newly created Chinese local governments were initially controlled by the adjacent provinces, whose influence was contested by Yigu. In one memorial, Yigu stated that even though the frontier military governors were not supposed to interfere with the jurisdiction of subprefectures, as land reform proceeded and thorny disputes between Han Chinese and Mongols increased, a unified civil administration as created by the military governors was indispensible. The unified civil administration allowed the military governors to coherently handle the Mongolian and Han Chinese affairs simultaneously. ${ }^{20}$

These developments greatly increased the administrative capacity of the frontier military governors. Yigu's influence rapidly grew among Han Chinese land speculators and migrants. As a result, the line previously dividing Han Chinese administration and frontier garrisons was trespassed. This happened at the same time that the frontier military governors expanded their influence in the Mongolian civil administration.

Fangken generated "a climate of opportunism" (Atwood 2002, p. 45) and spurred many poverty-stricken Mongol nobles to solicit favors from the military governors. Many petty nobles and even commoners strove to gain a share of land income. Gradually the banner governments were subjugated to the military governors. While dealing with the nobles' requests and petitions, the frontier military governors tried to circumscribe interventions from Lifan yuan, the main institution officially authorized to handle Mongolian affairs.

In 1901, in response to the Ulaanchab league's adamant rejection of opening its lands, Yigu appealed to Lifan yuan for assistance. The Guangxu emperor issued a decree that Lifan yuan should order the Ulaanchab and Yekhe Juu leagues to comply with the order (K. Li 1990, p. 133). However, as land reform progressed, Yigu's attitude toward Lifan yuan changed. In a supplementary memorial sent on September 8, 1905, Yigu bitterly reprimanded Lifan yuan for its inappropriate claim of sharing the benefits of land cultivation. ${ }^{21}$ Obviously, Yigu was trying to attenuate the control of Lifan yuan over the Mongol banners.

In short, the frontier military governors' efforts to monopolize control of both Han-Chinese subprefectures and Mongol banners resulted in the amal-

\footnotetext{
${ }^{20}$ See Yigu, "Zouwei zunyi Suiyuan jiansheng yi gu bianwei jin tiao ni dagai banfa gongzhe yangqi" [Memorial proposing the method of establishing a province in Suiyuan to consolidate the frontier defense], August 6, Guangxu year 33 (1907), collected in Yigu (1974, pp. 321-38).

${ }^{21}$ Yigu, supplementary memorial, September 8, Guangxu year 31 (1905), collected in Yigu (1974, pp. 369-70).
} 
gamation of the Manchu garrisons, the Han Chinese subprefectures, and the Mongol banners. All the pockets of multiethnic administration were placed under the supervision of the frontier military governors (fig. 3 shows the new Mongolian governance structure after the land reform). The integration of the frontier governance system paved the way for the new territorial division of Inner Mongolia in the early Republic of China. ${ }^{22}$ It also facilitated state control without, however, imposing a crude form of direct rule.

\section{Why Didn't Separatism Occur?}

According to center-periphery explanations, once the lax control over the periphery was tightened by the central state, the seeds of peripheral resistance and separatism would be planted. In the China case, land reform undoubtedly centralized state control of the Mongolian land, since the Mongols were deprived of the freedom to keep and sell their land. The original political autonomy of the Mongol banners was also curtailed because, after the reform, the banners had to appeal for approval from the frontier military governors when handling their own land affairs. It is true that compared with the Ottoman Tanzimat reform, land reform on the China-Inner Mongolia frontier lacked a strong agenda of cultural homogenization. ${ }^{23}$ Despite the low intensity of cultural homogenization, centralization itself should have generated great discontent among the Mongols, according to centerperiphery theory. Why did centralization fail to instigate Mongolian separatism in this case?

To explain this puzzle, we need to consider the structure of the frontier governance system. As an intermediate body, it shows strong characteristics of a brokerage system, with the frontier military governors acting as brokers between the center and periphery, Han and Mongols. I have shown how, by reducing the connections between Mongol banners and Lifan yuan, the frontier military governors mediated the center-periphery relationship. In the following discussion, I will use evidence of their activities to show how they mediated Mongol-Han interactions in the land reform.

\footnotetext{
${ }^{22}$ In 1912, Yuan Shikai (1859-1916), the president of the new Republic of China, ordered the Shanxi province to give up 12 counties (12 subprefectures under the Qing) under the Guisui circuit and put them under the supervision of Suiyuan jiangjun. Meanwhile he ordered the incorporation of Suiyuan town and Ulaanchab and Yekhee Juu leagues, making them into one special district (Zhang 1984, p. 57). In the same manner, Yuan ordered the establishment of Jehol and Chakhar special districts. These three special districts were led by the three military governors.

${ }^{23}$ Xiliang was another important military governor actively participating in the land reform. Among his memorials (Xiliang 1959), I found seven directly addressing the land issue, five on local administration, four on mineral exploration, three on taxation, two on military reorganization, five on bandits. Only two addressed educational matters.
} 


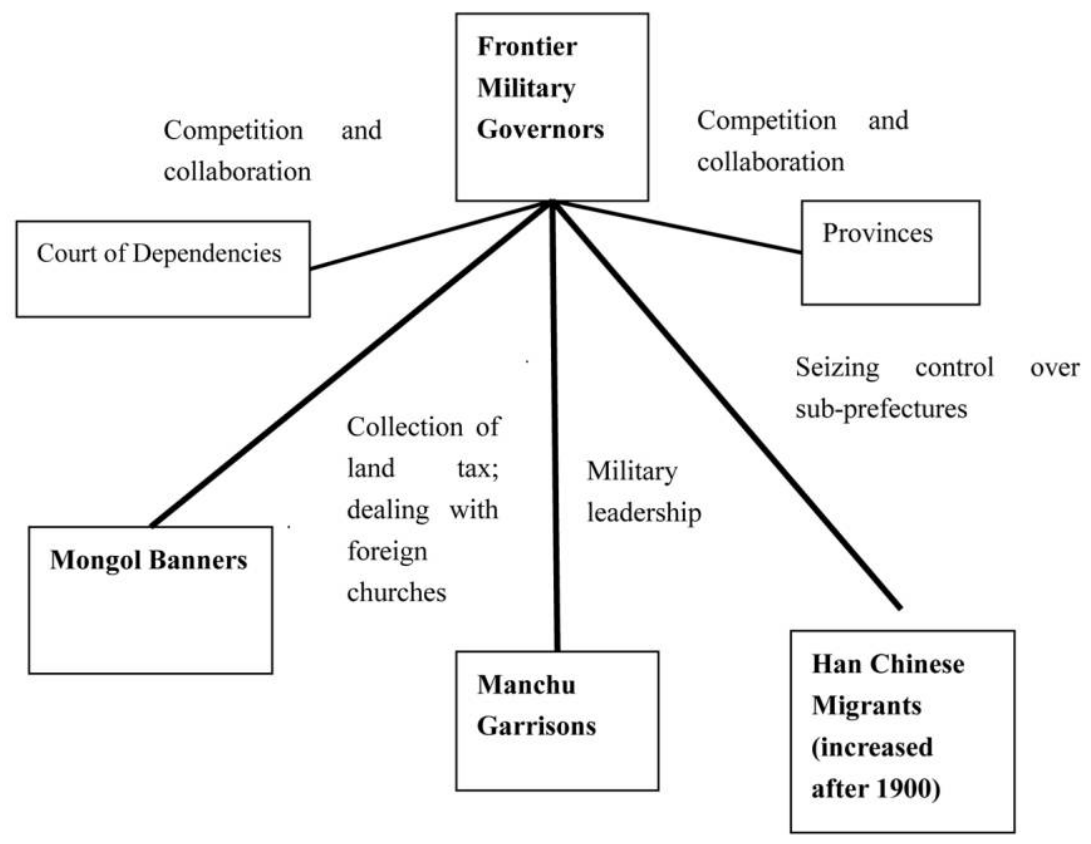

FIG. 3.-Inner Mongolian Governance Structure, 1900-1917

I will first reveal the collective identity of the frontier military governors, an important aspect illuminating their brokering ability. The change of collective leadership identity is highlighted in many studies on revolution and state formation. ${ }^{24}$ Categorizing the biographical data of early Soviet leaders, Riga (2008) discloses an interesting affinity between the minority middle-class elite and the Russian proletariat that explains the dual character of the Russian revolution as both a social revolution as well as a minority ethnic revolution. Prasenjit Duara's (1988) book on northern Chinese local politics also reveals that the reshuffling of local leadership is key to understanding state penetration in modern China. I will use biographical data to demonstrate that the brokering ability of the frontier military governors was not only attributed to the unique position they occupied in the frontier governance system, but also to their collective identity.

It is evident that before the domination of warlordism, the frontier military governors shared a common identity of "central state agents." I use this term to emphasize that most of the frontier military governors in this

\footnotetext{
${ }^{24}$ For example, Wilson (2011) discusses the influence of the identities of colonial officials on state building.
} 
period were not born or brought up on the frontier. They were outsiders, and this identity gave them the ability to play the role of brokers mediating the Mongol-Han interactions. When we study the educational backgrounds of the frontier military governors between 1900 and 1916 (see table 1), we find a consistent pattern. Most of the frontier military governors in this period obtained an elite education. They were normally civil examination degree holders; however, after the examination system was abolished in 1905, many graduated from prestigious state military academies. ${ }^{25}$ Among the eight prerevolutionary Manchu military governors, four had examination degrees just like normal Han Chinese bureaucrats. In addition to their education, they enjoyed wide bureaucratic networks through the rotation of governors in empire-wide military and civil posts (see the appendix). Many governors' careers were characterized by frequent transfers across frontiers, including Inner Mongolia, Outer Mongolia, and the Northeast. They also held positions in Lifan yuan at various points of their lives. Some of them, like the Han Chinese scholar-officials, held multiple positions in the central government (being Hanlin scholars) or local Chinese provinces (the best example is Xiliang). It is noteworthy that although Manchu governors were replaced by Han Chinese governors after the 1911 Revolution, this reshuffling did not change the nature of their collective identity.

It is logical to conclude that, before 1916, frontier military governors were central state agents, whose authority did not originate in the local political world. Resorting to the use of central-state agents to break down local obstacles to state penetration was a frequent strategy employed by early modern European monarchs in the creation of absolutist states (Beik 1985; Kettering 1986; Lachmann and Adams 1988). By placing frontier military governors above Mongol nobles in managing land affairs, Chinese emperors greatly strengthened the central-state presence on the frontier. Not rooted in local societies, central-state agents were often criticized for their relentlessly extractive activities in the process of European state formation. ${ }^{26}$ This however is less true in the China-Inner Mongolia case. As I will later show, frontier military governors acting as central-state agents tended to be more lenient toward both Mongols and Han Chinese migrants than their

\footnotetext{
${ }^{25}$ The rise of militarism in the late Qing period is a significant phenomenon. A large proportion of young Chinese students joined military schools as an alternative career option when the examination system was abolished. Beiyang Military Academy was established by Li Hongzhang (1823-1901) in 1885. The school adopted a German-style modern military education with the goal of training elite military officials for China. Nearly all of the most eminent graduates became influential political figures in the early Republic of China. For that reason, the early Republican government was also called the "Beiyang government."

${ }^{26}$ This has been a classic statement ever since Alexis de Tocqueville. Duara (1988) has a similar argument about the degeneration of local politics in the process of centralization in modern China.
} 


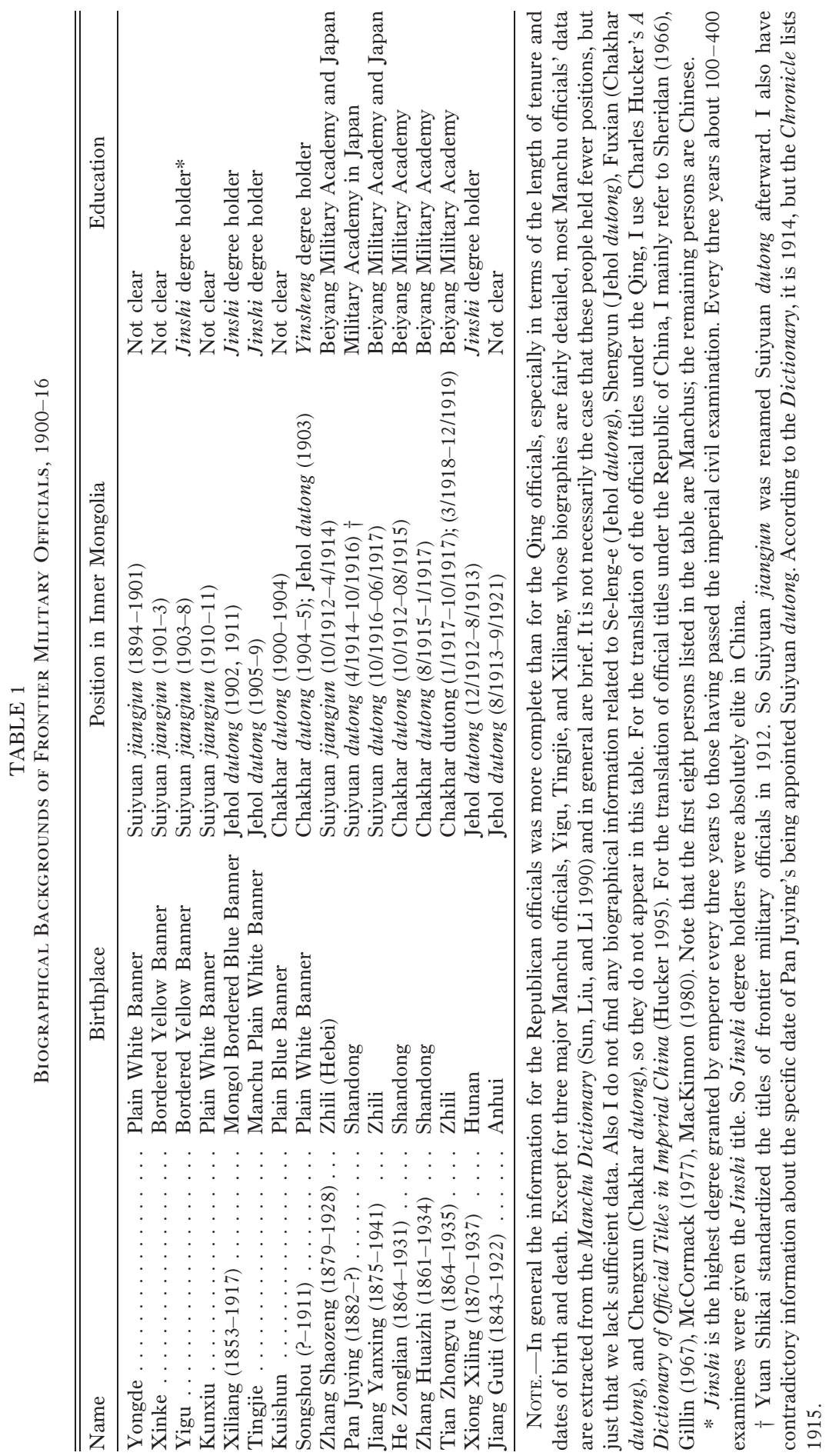

This content downloaded from 147.008.230.123 on August 23, 2016 19:30:56 PM 
counterparts patronized by local warlords. The "outsider" identity gave them credibility to collaborate extensively with indigenous groups, both Mongols and Han Chinese, without completely aligning with either of them. Quite ironically, as this brokerage system became more integrated, its intermediate character also became more significant.

The frequent interactions among frontier military governors, Mongol banners, and Han Chinese migrants in administering land affairs encouraged the growth of solidarity among these three. This was already shown in the ways frontier military governors endeavored to ward off the interference of Lifan Yuan and neighboring Han Chinese provinces in the land reform operation. Neither did the frontier military governors entirely identify with the Mongols or the Han Chinese migrants. Instead they brokered MongolHan interactions.

The frontier military governors assured Mongols that their main intention was not to reap land profits on behalf of the state, but to eliminate the vices of private land cultivation that had pained the Mongols for years. By disallowing private land transactions between the Mongols and Han, frontier military governors representing the state became the sole authorities mediating the Mongol-Han land relationship. As Yigu stated, "In the old times, the Mongol land was forbidden to be cultivated. However, private cultivations started early. For current Mongols, their livelihood no longer depends upon grazing but upon agrarian production. Given that private cultivation has become popular, it is better for the state to organize and regularize it, so that Mongols would obtain benefits, while corruption and exploitation involved in private cultivation would be reduced." ${ }^{27}$

Yigu also established the East Company of Land Reclamation primarily to counteract the monopoly of big Han Chinese land merchants. He proudly stated that among the total of over 300,000 taels gained by the East Company, only 70,000 taels were shared by land merchants. ${ }^{28} \mathrm{He}$ further rebuked incorrect land measuring, which caused a big loss of benefit to the Mongols. Not specifying the location and size of land in private land contracts gave

\footnotetext{
${ }^{27}$ Suiyuan tongzhi gao (Suiyuan Gazetteer) was composed by Suiyuan tongzhi guan in 1937. It is the most complete local history of Inner Mongolia. It contains primary sources on the major events happening in Suiyuan history, especially in the early Republican period. This collection sustained some damage during the Sino-Japanese war. After the war, about 113 volumes remained intact. I used the most recently edited version (2007), published by Neimenggu renmin chuban she, which contains 100 volumes. The quotation comes from Qing Guanxu jian Yigu zhuban mengken shimo [Chronicle of Yigu's supervision in Mongolian land cultivation], collected in Suiyuan tongzhi guan (2007 [vol. 38], p. 194).

${ }^{28}$ See Qing Guangxu jian Yigu zhuban mengken shimo [Chronicle of Yigu's supervision in Mongolian land cultivation], collected in Suiyuan tongzhi guan (2007 [vol. 38], p. 195).
} 
rise to enormous land disputes as time went on. ${ }^{29}$ Worse than that, without official regulations, Yigu noted, "fake tenants occupied the land. Some unruly tenants refused to pay their rent. As a result, Mongols lost their subsistence, because they lost their land through the extended chains of tenancy. Some greedy Mongols colluded with sneaky Han Chinese and rented the same plot of banner common land to multiple tenants. These tricks gave them immense profits at the expense of the interests of the majority of Mongols."30

Banning private land cultivation henceforth cut off direct land transactions between Mongols and Han, consequently mitigating land disputes between them. In addition, frontier military governors adapted policies to suit the divergent needs of Mongols and Han Chinese migrants.

When providing compensation to Mongols who lost their land, the frontier military governors avoided a uniform and clear-cut policy. They tried to accommodate the complex classifications used by the Mongols to differentiate the status and privileges of land. It could be wild/cultivated land (based upon its cultivation status), good/medium/poor land (based upon its location and fertility), or various categories of privileged land. Privileged land was granted as a means to show imperial favor to certain officials, banner governments and garrisons, and individual herdsman. It included land owned by local subprefecture governments, the rice lands of the Suiyuan government, the land of post relay stations, and the land of Manchu princes who married Mongol nobles. It also included the subsistence land of Mongol nobles and commoners, official grazing land, the land of those households without descendants, and temple lands, among others. I call these lands "privileged land" to emphasize that they were treated differently from the ordinary land. They were not subject to being opened, and greater compensation was usually paid if they were. ${ }^{31}$

To the Han Chinese migrants who paid for land licenses and land taxes, frontier military governors tried to adapt to their diversity as well. They distinguished between wild (shengdi) and cultivated land (shudi), the latter designating land privately rented out by individual Mongol nobles to Han peasants before fangken. Both kinds of land were surveyed and opened under strict supervision, but the price of a license for each differed. The

\footnotetext{
${ }^{29}$ See Yigu's memorial sent on Dec. 2 of Guangxu year 27 (1901), Kenwu zouyi [Yigu's Memorials about land cultivation], collected in Suiyuan tongzhi guan 2007 [vol. 38], p. 204.

${ }^{30}$ See Can an diaocha ji (Investigation of Yigu's Misdemeanor in Land Reclamation), Guangxu year 31 (1905), collected in Suiyuan tongzhi guan (2007 [vol. 38], p. 235).

${ }^{31}$ For more details, see Can an diaocha ji, collected in Suiyuan tongzhi guan (2007 [vol. 38], p. 269).
} 
tenants of wild land paid more to get the license than did those seeking cultivated land. ${ }^{32}$

To reassure the Han Chinese migrants, the frontier military governors made great efforts to reduce land prices, postpone the deadlines of rent payments, increase loans of grain seeds, and lend peasants plow instruments. They also facilitated the establishment of irrigation systems and provided other assistance. ${ }^{33}$ They granted a five-year grace period to migrants before their land became taxable. On many occasions, that grace period could be extended up to eight years. ${ }^{34}$

The stabilization of Han Chinese settlements was vital to the consolidation of the frontier governance system because the funding for local government came from the Han Chinese migrants who purchased licenses and paid rent. Without these funds, the local administration could barely undertake infrastructure development, such as constructing roads and building schools. Without the migrants, the extra fiscal burdens would have been imposed on the Mongols. Moreover, the Han Chinese migrants also financially supported the Mongolian communities. A great portion of the income from selling land licenses to Han Chinese migrants went back to the Mongol banners and lamaseries, which lost land ownership in the reform. Stabilizing the situation of Han Chinese migrants therefore allowed the evolution of complementary political and economic relationships with Mongols.

In sum, although land reform greatly reduced Mongolian autonomy in land ownership and governance while simultaneously increasing state authority on the frontier, it did not provoke Mongolian separatism. The main reason for this is that the reforms consolidated an intermediate body of governance rather than imposing a crude form of state control. This intermediate body was a brokerage system that centered on the frontier military governors, who successfully mediated center-periphery relationships, including the land relationship between Mongols and Han Chinese. Mongols lost the right to deal freely with their land, but they gained great compensation from Han Chinese migrants who bought licenses to cultivate the land. Although freed of the tax obligation, Mongols did not completely part with their land because they claimed a great share of the land rents and even some part of the land taxes. On the other hand, Han Chinese migrants obtained arable land that was unavailable in other parts of China.

${ }^{32}$ Ibid.

${ }^{33}$ See Qing Guanxu jian Yigu zhuban mengken shimo [Chronicle of Yigu's supervision in Mongolian land cultivation], collected in Suiyuan tongzhi guan (2007 [vol. 38], p. 20). ${ }^{34}$ Yao Xiguang, Choumeng chuyi [Preliminary suggestions on the management of Mongolian affairs], 1908. This document is a historical source dated. Yao Xiguang was a late Qing official known for his experienced insights on frontier matters. The source is collected in Neimenggu tushuguan (2008, pp. 38-39). For more on the conservation of the Mongolian prerogatives in land, see Wang (2014). 
The migrants paid land rent and taxes, at a price considerably lower than in other places in China. They were thus willing to take on the economic burden of supporting local government operations. Thus, through the mediating efforts of the frontier military governors, land cultivation did not become a devastating event exacerbating the Mongol-Han relationship that gravely jeopardized the interests of the minorities. Instead it generated a complementary relationship between Mongols and Han Chinese migrants. The operation of this brokerage system ensured that although a significant degree of centralization was ongoing, its pressure was diffused and thus did not provoke minority separatism.

\section{REVOLUTION AND THE INTERREGNUM PERIOD}

What happened through the land reform reveals that state centralization was embodied not by the growth of the central state apparatus, but by the growth of the brokers' power, that is, the frontier military governors, who were the hinge connecting the center and periphery, Mongols and Han Chinese. After land reform, China underwent another series of events epitomized by the 1911 Revolution, a Chinese nationalist revolution that overthrew nearly 300 years of Manchu rule. The collapse of Manchu rule and the substitution of frontier governors by the Han Chinese was expected by some to bring an unprecedented crisis of Mongolian separatism in the frontier (Crossley 2005; Esherick 2006; Friskesjo 2006). Yet, this possibility did not materialize. Again focusing on the intermediate body of governance, I will explain this puzzle.

Contrary to the expectation that Mongols would split from the new Chinese republic, my findings, based on new archival sources, show that Mongols continuously adhered to the leadership of the frontier military governors even when the latter were not Manchu but Han Chinese. The functioning of the brokerage system seemed undisturbed by the switch from Manchu to Han Chinese military governors. Not only the Mongols, but also the Han Chinese migrants exhibited a strong inclination to keep the frontier governance system intact. The Mongols might have been vaguely worried about the downfall of the Manchu rule and the upcoming Chinese nationalist republic, but this general concern did not translate into specific hostility toward the domination of Han Chinese military governors, nor toward local Han Chinese migrants. Instead, Mongols continued to collaborate with the Han Chinese migrants, under the mediating efforts of the frontier military governors. The frontier seemed to be buffered from the calamitous repercussions generated by the collapse of the imperial center.

Other than temporary disorder, the most important repercussion was caused by the new Republic's attempt to unify the frontier administration. In 1912, Lifan yuan was renamed Mengzang shiwu ju (Bureau of Mongo- 
lian and Tibetan Affairs). This new institution was subordinate to the direct leadership of Nei wu bu (Department of Domestic Affairs) rather than the president of the Republic of China. Its formation went in tandem with new policies formally annulling the "dependency" status of Mongols. These efforts at homogenizing, or sinicizing, frontier institutions were at first resisted by the frontier military governors, who, though being Han Chinese, refused to follow the orders of the central government.

Zhang Shaozeng was then Suiyuan jiangjun, leading a garrison army overseeing the security of the western leagues of Inner Mongolia. In his petition to the Bureau of Mongolian and Tibetan Affairs on November 13, 1912, Zhang claimed that the announcement of April 21, 1912, was at the root of Mongolian dissent. ${ }^{35}$ That announcement sketched out the basic principle of wuzu gonghe ("The Republic of Five Nations") and highlighted the goal to eliminate the fanshu (literally translated as "the dependencies") status of frontier peoples. Remonstrating on behalf of the Mongols, Zhang pleaded for the central government to hold off on administrative unification. He emphasized that most Mongol nobles would resent the abolition of dependencies, because they suspected that this would destroy their traditions and religion. A similar intervention was made by Rongxun, a Mongol official then entrusted by president Yuan Shikai to pacify the Mongols in the northeast in $1912 .^{36}$

These interventions show that the new republican government attempted to centralize administrative control and standardize frontier governance. They also show that this attempt was resisted (at least somewhat) by frontier governors. It seems that the ethnic identity of the military governors was not pertinent to their ability to function in the frontier governance system. Administrative unification was a goal not only pursued by the central government, but also by the neighboring Han Chinese provinces that wished to expand territorial control by formally annexing Han Chinese governing units located in Inner Mongolia. Although facing this encroachment from both sides, Mongols and Han Chinese migrants were not split by their ethnic differences.

In an attempt to encroach upon the Mongolian administration, the neighboring Han Chinese provinces tried to move the administration of the Han

${ }^{35}$ Yimeng Suiyuancheng Cha-ha-er dutong deng guanyu difang zhidu deng wenti gei
Meng zang yuan zi cheng deng gongwen [Official reports sent by Suiyuan jiangjun and
Chakhar dutong about the issues of local institutions and etc.], Meng Zang Yuan
Dang'an (hereafter MZYD), Quanzongjuan 440, anjuanhao 23. The MZYD are the
archives of the Department of Mongolian and Tibetan Affairs. I consulted copies of this
source now located at the Center of Mongolian Studies at Inner Mongolian University.
The original source is located at the Second Historical Archives of China in Nanjing.
${ }^{36}$ The report sent by Rongxun (the vice director of the Bureau of Mongolian and
Tibetan Affairs) to the president and the prime minister on November 23, 1912, Da-
zongtong, Mengzangyuan dui ge mengqi youguan difang zhidu zi cheng chentiao deng 
Chinese migrants under provincial control. However, the migrants showed a strong inclination to align with the frontier military governors rather than the neighboring Han Chinese provincial authorities. In a letter sent by the Jehol Native Association (Re-he tongxiang hui) to the president and the Guo wu yuan (State Council), ${ }^{37}$ the leaders of the Han Chinese migrants in Jehol stated that they, like the Mongols, preferred to stay under the administration of the Jehol military governor. They objected to administrative partitioning with the Mongols and disliked the idea of being transferred to the direct administration of the Zhili province. They implored the central government not to endorse this provincial ambition. They insisted that the newly created Chinese administrative units in Chifeng and Chaoyang should still be placed under Jehol rather than the Zhili administration. They even went so far as to suggest converting Jehol into a special administrative region, so as to completely sever its connections with Zhili province.

Like the Han Chinese migrants, the Mongols perceived a threat in the movement toward administrative unification. They recalcitrantly objected to annexation by the neighboring Zhili province of the Han Chinese administration in Jehol. In the telegraph sent by the Kharachin right-wing banner in $1912,{ }^{38}$ the Kharachin prince declared that he was offended by the idea of splitting the Han Chinese from the Mongolian administration and allocating the former to the control of Zhili province.

The reactions of the Kharachin prince, the Chinese migrant elite, and the frontier military governors show that these three parties were united in their opposition to administrative unification. Their common interests, in-

gongwen de zhaofu [The president's and the Department of Mongolian and Tibetan Affairs' responses to the reports and petitions on the local institutions of the Mongolian banners and leagues], MZYD, Quanzongjuan 440, anjuanhao 22.

${ }^{37}$ The letter sent by the Jehol Native Association to the President and Guowuyuan [undated; but judging from the response sent back by the Bureau of Mongolian and Tibetan Affairs, the letter was probably written before October 15, 1912], Yimeng Suiyuancheng Cha-ha-er dutong deng guanyu difang zhidu deng wenti gei Mengzangyuan zi cheng deng gongwen [Official reports sent by Suiyuan general and Chakhar dutong about the issues of local institutions and etc.], MZYD, Quanzongjuan 440, anjuanhao 23.

${ }^{38}$ Telegraph sent by Kharachin right-wing banner to the president, the state council, senate and the Bureau of Mongolian and Tibetan Affairs, on November 22, 1912, Yimeng Suiyuan cheng Cha-ha-er dutong deng guanyu difang zhidu deng wenti gei Mengzangyuan zi cheng deng gongwen [Official reports sent by Suiyuan general and Chakhar dutong about the issues of local institutions and etc.], MZYD, Quanzongjuan 440, anjuanhao 23. The Kharachin prince's concern was explicit in the message sent by Lu Zhongdai, the person sent by the central government to collect information in Inner Mongolia. See Lu's telegraph sent to the president, the state council, the bureau of Mongolian and Tibetan Affairs on December 1, 1912, Yimeng Suiyuancheng Cha-ha-er dutong deng guanyu difang zhidu deng wenti gei Mengzangyuan zi cheng deng gongwen [Official reports sent by Suiyuan general and Chakhar dutong about the issues of local institutions and etc.], MZYD, Quanzongjuan 440, anjuanhao 23. 
cipiently growing out of the land reform, were fortified after the outbreak of the revolution. Their resistance supports my argument that the frontier governance system, as an intermediate body, was an important buffering agent between the center and periphery in China. This highly integrated system cushioned the repercussions of the revolution and the succeeding regime's administrative unification (or homogenization) initiatives. The new republican government quickly realized that to harness, rather than break down, this intermediate linkage would be more beneficial to the stability of the frontier. ${ }^{39}$

In sum, the 1911 Revolution eliminated Manchu rule and unleashed temporary disorder. After the revolution, both the central government and the neighboring Han Chinese provinces embarked upon plans for administrative unification. These changes might have provoked or generated opportunities for Mongolian separatism, but that did not happen. This anomalous result is largely attributable to the stability of the frontier governance system. Unfortunately, the equilibrium maintained by that system met a real challenge following the rise of provincial warlordism in the 1920s. The frontier governance system quickly fell apart thereafter, and Mongolian separatism emerged at that historical juncture.

\section{ETHNIC SEPERATISM AND WARLORDS' RULE, 1917-27}

A new level of political fragmentation emerged in the late 1910s, after the death of Yuan Shikai, the charismatic leader of the early Republiccan government. In the absence of a strong center, various northern Chinese provincial governors attempted to expand their own influence. These people became belligerent warlords, using their provincial bases to build up local states for the purposes of combating each other. The warlords tried to annex parts of the frontier to their own provincial territories. In the scramble for the Mongolian frontier, they used their own confidants to replace former frontier military governors. Consequently, the brokerage system was shattered. Inner Mongolian separatism broke out at this juncture.

\section{The Rise of Warlordism}

Yuan Shikai's death in 1916 marked the critical turning point, changing China from a relatively unified regime to a fragmented one. None of Yuan's

${ }^{39}$ The document sent by the Bureau of Mongolian and Tibetan Affairs to the Guowuyuan on October 15, 1912, Yimeng Suiyuancheng Cha-ha-er dutong deng guanyu difang zhidu deng wenti gei Mengzangyuan zi cheng deng gongwen [Official reports sent by Suiyuan general and Chakhar dutong about the issues of local institutions and etc.], MZYD, Quanzongjuan 440, anjuanhao 23. 
successors (e.g., Li Yuanhong [1864-1928], Duan Qirui [1865-1936], Feng Guozhang [1859-1919], Cao Kun [1862-1938] and others) were able to maintain even a semblance of unification. ${ }^{40}$ According to Chi Hsi-sheng (1976, p. 2), from 1926 to 1928 , the cabinet was reshuffled about 24 times and 26 persons held the post of prime minister. The longest tenure was 17 months, and the shortest was two days. The average tenure ran from three to five months.

Before 1920, political competition was confined to factions within the central government and did not involve local militarists. ${ }^{41}$ Duan Qirui, Feng Guozhang, and Cao Kun, each of whom served as president, were all outstanding graduates of the Beiyang Military Academy. Things changed after 1920 when local power contenders joined the competition for political authority at the center. After Feng Guozhang's death, the discord between Feng's successor, Cao Kun, and Duan Qirui magnified, eventually driving the outbreak of the Anfu-Zhili War in 1920. Zhang Zuolin (1875-1918), a local warlord in Manchuria who had grown to be the most daunting power holder in the northeast, joined the war and aligned with Cao. ${ }^{42}$ In 1922 and 1924, respectively, two wars broke out between Zhang Zuolin and Cao Kun, prefacing warlordism in China. Two other warlords also became rising stars in the 1920s political theater of north China-Feng Yuxiang and Yan Xishan.

Feng Yuxiang was both an enemy and an ally of Zhang Zuolin. He acquired his first territorial base in 1921 while serving as the military governor of Shaanxi (for details, see Jiang [2003], pp. 54-55). After the first ZhiliFengtian War in 1922, Feng obtained the territory of Henan. Yan Xishan had acquired his territorial base much earlier, before the 1911 Revolution. A Shanxi native, he graduated from Shanxi Military Academy and initiated an impressive military reorganization in Shanxi as early as $1911 .^{43}$ Yan

\footnotetext{
${ }^{40}$ Once the revolution first broke out in southern China, the postrevolutionary central government only nominallv retained control over the southern provinces. After 1911, the term "Chinese central government" mostly refers to the northern government.

${ }^{41}$ Before 1920, the most powerful local militarists, such as Zhang Zuolin (1875-1928), Feng Yuxiang (1882-1948), and Yan Xishan (1883-1960), each of whom played a significant role in frontier politics during the 1920s, were still minor figures. For details see Sheridan (1966, pp. 37, 51, 100) and Gillin (1967, p. 23).

${ }^{42}$ Zhang moved to the center of the political stage in the northeast only after the revolution erupted. To defeat the disobedient revolutionary forces, the Qing court summoned Zhang Zuolin's provincial army for help (McCormack 1977, pp. 18-25). After the revolution, Zhang continued to build up his power with a local focus in Fengtian province (present-day Liaoning). He was able to expand his domination into Heilongjiang in 1917 and Jilin in 1919, incorporating the three northeastern provinces under his control (McCormack 1977, pp. 34-36).

${ }^{43}$ By 1911, Yan Xishan was still a regiment commander in the Shanxi army. His military reform programs included recruiting more native Shanxi soldiers. See Yan Bochuan xiansheng jinian hui (1988, pp. 33-34).
} 
appeared to be less ambitious than Feng Yuxiang or Zhang Zuolin, although he steadily secured domination in Shanxi through a strategy of isolation - not fully engaging in these factional wars.

These three major warlords consecutively monopolized Chinese northern politics before Chiang Kai-shek's Northern Expedition in 1927. The period of 1917-27 saw the fragmentation of northern politics, due to the collapse of central government and the rise of local warlords. Since these warlords' territorial bases were provinces abutting the Inner Mongolian frontier, their domination profoundly affected the stability of the Inner Mongolian governance system.

\section{A New Change in the Governance Structure}

The provincial warlords' regimes generated a new reservoir of frontier military governors. The educational backgrounds and administrative experiences of the military governors in Inner Mongolia between 1917 and 1928 display an entirely different pattern than was typical of those who served in that role before 1917. This new pattern became discernible around 1920 (see table 2 and app. table A2), a critical time when local warlords started participating in a nationwide competition for political power. Between 1917 and 1920, there was no abrupt deviation in the composition of frontier military governors. Consistent with the pattern before 1916, three Suiyuan $d u$ tong (Jiang Yanxing, Chen Guangyuan, and Cai Chengxun) were all graduates of the Beiyang Military Academy. The two Chakhar dutong (Tian Zhongyu and Wang Tingzhen) were also Beiyang Military Academy graduates. Another Chakhar dutong, Zhang Jinyao, graduated from Baoding Military Academy, the school established by Yuan Shikai to succeed the Beiyang Military Academy.

The case of Jehol dutong is slightly different, because the major dutong, Jiang Guiti, who retained control the longest, did not have any formal education. His prestige was mainly based upon military performance. Jiang was an old member of the Yi army, a branch of Li Hongzhang's Huai army, which was the most powerful military organization before the establishment of Beiyang Military Academy. Despite this difference, Jiang, like his peers, had a career colored by nationwide administrative experience before taking the position in Inner Mongolia.

These leaders were the last vestige of an eclipsing cohort of central state agents. Their influence decayed after 1920 when local warlords moved into the national political theater. Chen Guangyuan and Cai Chengxun retired in 1924 after the defeat of the Zhili clique in the war. Tian Zhongyu was deposed in 1923. That same year, Wang Tingzhen resigned, disappointed by the civil war. Jiang Guiti died earlier, before the civil war fully exploded. Only Zhang Jingyao was still active in politics after the 1920s. He first 


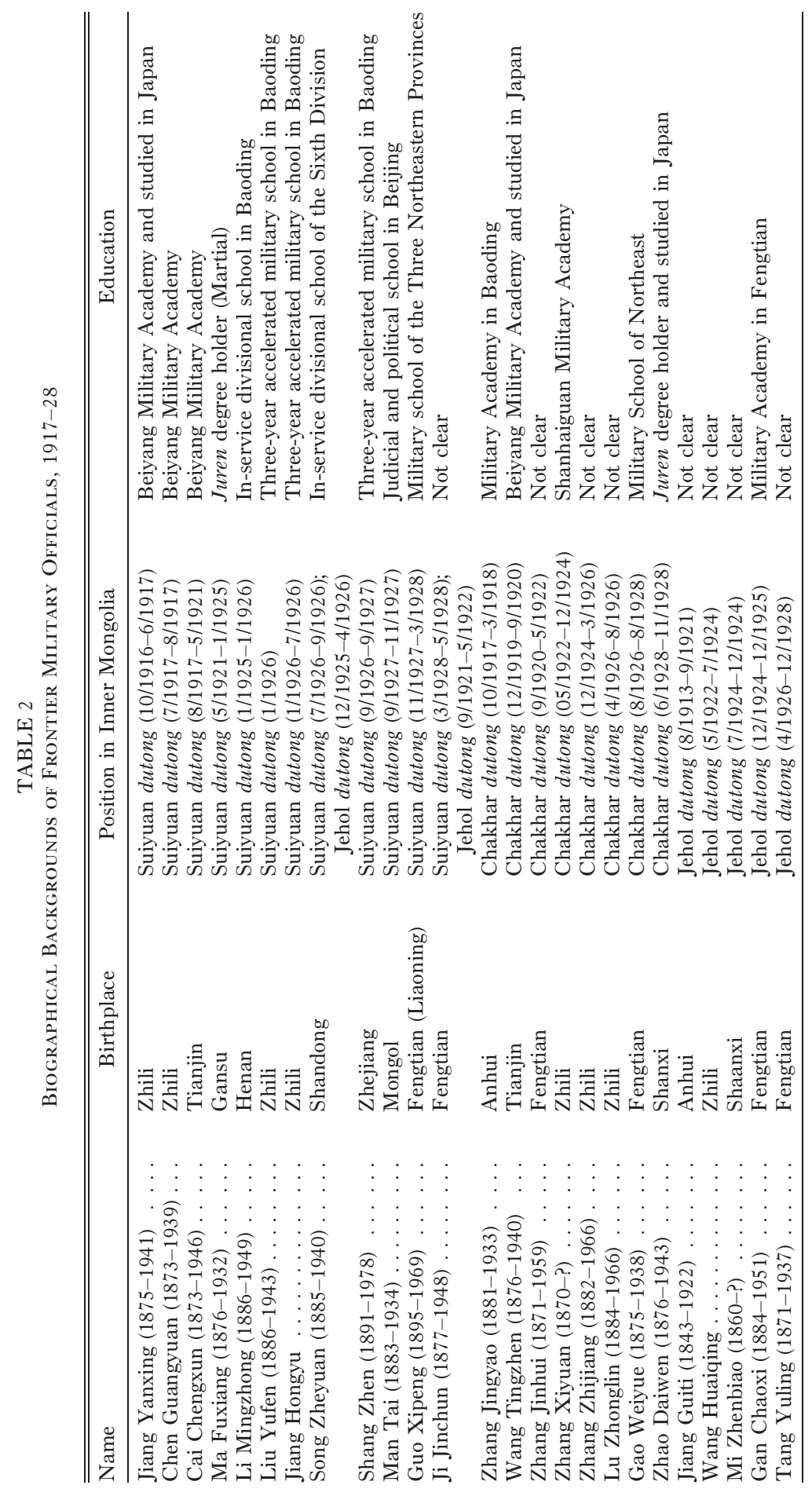

This content downloaded from 147.008.230.123 on August 23, 2016 19:30:56 PM All use subject to University of Chicago Press Terms and Conditions (http://www.journals.uchicago.edu/t-and-c). 
joined with Zhang Zuolin and Zhang Zongchang and then went on to join the Japanese puppet government in Manchuria (Manchuko). This last vestige of central state agents had almost disappeared from frontier politics in the early 1920s. Their retreat left vacancies to be occupied by confidants of the local warlords.

After 1920, a new group of officials emerged who were protégées of the rising local warlords (see app. table A2). Fourteen of them had strong ties with the three major local warlords. Six were trustworthy subordinates of Feng Yuxiang. Some (e.g., Zhang Zhijiang) were close comrades of Feng while he was still a petty official in the Northeast. Some (e.g., Liu Yufen, Song Zheyuan, Zhang Zhijiang, Lu Zhonglin) grew up in the 16th mixed brigade of the Chinese army (then called the Beiyang army) directly commanded by Feng in his early years. Others (Li Mingzhong and Zhang Zhijiang) enjoyed Feng's patronage in Henan and Shaanxi. In a similar fashion, six confidants of Zhang Zuolin (e.g., Guo Xipeng, Ji Jinchun, Zhang Jinhui, Gao Weiyue, Gan Chaoxi, and Tang Yulin) all grew up in Zhang's Fengtian army.

The background of Yan Xishan's protégées, Shang Zhen and Zhao Daiwen, was less clear-cut. Shang joined the new army in the northeast before the revolution and briefly worked in the army dispatched to Shaanxi under Lu Jianzhang's leadership. Despite this overlap with Feng Yuxiang, Shang Zhen joined Yan Xishan in 1915 and loyally served the Shanxi army thereafter. Zhao Daiwen was a distinguished civilian official, but also a core member of the Shanxi clique. ${ }^{44}$ All of these officials had narrow administrative experiences. They exclusively worked for individual warlords.

Compared to their predecessors, these men were characterized by an inferior education (see table 2). Among them, five (Li Mingzhong, Liu Yufen, Jiang Hongyu, Shang Zhen, Zhang Jingyao) officially graduated from the military school in Baoding. One, Song Zheyuan, received a short, informal military training in the in-service divisional school of the Sixth Division. Three (Guo Xipeng, Gao Weiyue, and Gan Chaoxi) were educated locally in military schools in the northeast sponsored by Zhang Zuolin himself, while three others (Zhang Zhijiang, Lu Zhonglin, and Tang Yuling) do not seem to have had any formal education; their military careers began in the ranks.

\footnotetext{
${ }^{44}$ The other five people were singular cases that had more ambiguous connections. Ma Fuxiang was a Muslim general whose power was steadily stabilized in the Gansu and Qinghai regions where the Muslim Chinese (the Hui people) predominated. Therefore Ma was not a negligible person in northwestern politics. Rather, he was deemed an influential balancing power in the northwestern frontier and was frequently appealed to by multiple competing forces in Inner Mongolia. Mantai was a Mongolian revolutionary and his brief tenure as Suiyuan dutong was nothing more than an accident. Zhang Xiyuan was a semiloyalist to Feng Yuxiang because he joined Feng Yuxiang only after the defeat of the Zhili clique. He did not belong to Feng's core, as is demonstrated by the fact that he retired after 1924 .
} 
Two (Ji Jinchun and Wang Jinhui) were outlaws before joining Zhang Zuolin's forces.

These new military governors no longer represented a "disinterested" third party and could no longer play the role of brokers in handling frontier affairs. Being protégées of local warlords, they worked for the warlords' regimes and heralded the Chinese provincial expedition into the Mongolian frontier. Figure 4 illustrates the Inner Mongolian governance structure during the period of warlordism.

This new structure shows that a unified central government was replaced by competing regional governments headed by Chinese warlords. The Department of Mongolian and Tibetan Affairs, the counterpart to Lifan yuan, no longer actively functioned. Concomitantly, there was a sharp decrease in the archives (only five documents exist) for the department. ${ }^{45}$ The collapse of the center as well as the expansion of provincial warlordism completely shattered the brokerage system established during the land reform process.

\section{What Triggered Separatism}

Like the warring states in early modern Europe, the domination of warlordism resembled a multipolar political system that increased insecurity and the speed of military mobilization and resource extraction. The national estimated growth of armies over this period is notable: in 1916 the army is more than 500,000 men, in 1918 more than 1 million men, in 1924 more than 1.5 million men, and in 1928 more than 2 million men (Chi 1976, p. 78). By summer 1925, Feng Yuxiang controlled over 100,000 capable soldiers. ${ }^{46}$ In September 1925, Zhang Zuolin's northeastern army amounted to 350,000 men, not including the Jehol and Shandong units, almost doubling the size of the army before the 1924 war (McCormack 1977, p. 147). Even Yan Xishan, the least aggressive warlord, recruited over 100,000 men after the Zhili-Fengtian War (Gillin 1967, p. 109).

Intensive military competition generated the necessity for increased and excessive economic extraction, a factor contributing substantially to regional centralization. Yan Xishan was well known to be tightfisted. However, in 1928 , the expenses of his provincial government were $350 \%$ greater than in 1925 and the annual deficit roared from 685,571 yuan to 13,647,000 yuan,

\footnotetext{
${ }^{45}$ See MZYD, Quanzongjuan 440, anjuanhao 22, 23, 24.

${ }^{46}$ Strictly speaking, this is just the number of the first Citizenry Army directly commanded by Feng Yuxiang himself. The second and the third versions of the Citizenry Army, led by Feng's subordinates, were less well organized. The second army expanded rapidly too, and by summer 1925 it numbered about 250,000 men. The third army numbered over 30,000 men. For details, see Sheridan (1966, pp. 160-63).
} 
From Masterly Brokers to Compliant Protégées

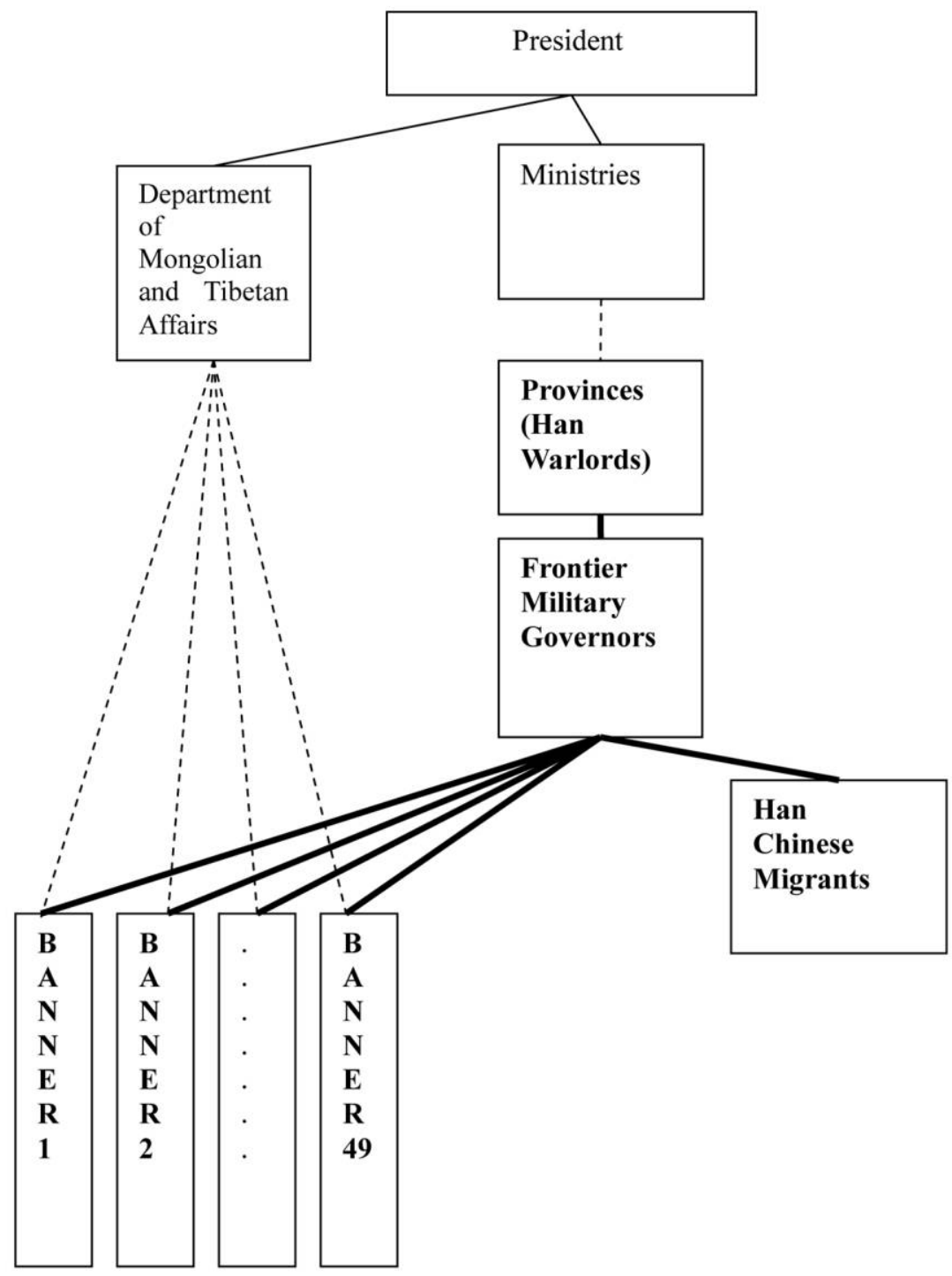

FIG. 4.-Inner Mongolian Governance Structure, 1917-1927

despite a sharp increase of taxation revenue (Gillin 1967, p. 110). To expand income, some warlords increased taxation and relied on diverse foreign loans (e.g., Zhang Zuolin depended on Japanese loans, whereas Feng Yuxiang relied on Soviet support). Some of them resorted to illegal means, manipulating currency value and profiting from opium cultivation. 
The frontier suffered from this massive economic exploitation, as more radical land cultivation projects were undertaken by the warlords' regimes. Feng Yuxiang, marshal of the Northwestern Defense, set up headquarters in Chakhar in 1925. With the support of the frontier military governors, he embarked upon a five-year plan to develop and populate this region (Sheridan 1966, pp. 149-51). According to Desheng Wang (1987, p. 79), the land values for those areas surveyed and opened between 1912 and 1928 skyrocketed. From 1912 to 1917, the land annually opened fewer than 1,500 qin. From 1917 to 1926, it exceeded 17,000 qin, reaching a peak in 1925-26, with 36,000 qin land opened. Then it slowed down, but still more than 3,000 qin of land opened every year.

In the new rush for land cultivation, the frontier military governors, being completely compliant with the commands of their warlord patrons, no longer played the role of brokers. On the contrary, they sided with the warlord regimes and aroused animosity from both Mongols and Han Chinese migrants. For example, the ownership of the official grazing land and the subsistence land of the households with no descendants ( $j u e h u d i$ ) was never clearly defined in local tradition. Facing this ambiguity, Yigu ordered that the rent collected from these lands should go to the banner government. ${ }^{47}$ However, the new rule implemented by Shang Zheng, a protégée of Yan Xishan, in 1926 declared:

(Article Seven) Those lands having nonresident owners and without tenants have been fallow for some time, which is a big loss to the government. So the local governments [Han Chinese counties] should let people know that these lands have been officially confiscated. As long as the land was fallow over 5 years, it should be confiscated, just like the subsistence land of the households with no descendants. ${ }^{48}$

The new policy dictated that those lands with unclear ownership were considered provincial, rather than the Mongolian, property. They were confiscated to maximize the warlords' wealth. These actions contravened the principle underlining the previous land reform, that is, insofar as the land was located within Mongol banners, the Mongolian interest always took priority.

Moreover, since the warlords no longer seriously considered Mongolian rights in the opened land, they also attempted to reduce diversity in land classification and thus streamline the land policy. In 1927, the land recla-

\footnotetext{
${ }^{47}$ See Can an diaocha ji, Suiyuan tongzhi guan (2007 [vol. 38], p. 270).

${ }^{48}$ Zhengdun huangzu chufen tiaoli [Regulations about the rent of wild land], collected in Suivuan tongzhi guan (2007 [vol. 38], p. 369).
} 
mation bureaus controlled by Suiyuan dutong announced that the privileged land given by the Tümed Banners to the Manchu princess should be elevated to taxable land just like the regular land. It claimed that "within the same county, to adopt two methods, is not good for the polity." Most Mongol nobles were infuriated by these changes, and their antagonism toward the Han Chinese warlords grew. This evidence reveals that the frontier military governors in this period aligned completely with the Han Chinese warlords, whose immediate concern was economic extraction, not balancing the Mongol-Han relationship.

To the Han Chinese migrants, the warlords' rule was equally oppressive. Not interested in nourishing the Chinese settlers, the warlords and their agents took money for irrigation and increased the taxation on most peasants. A great number of desperate Chinese peasants fled. The land they purchased soon became fallow, and the rent they owed to the Mongols was never paid. The departure of Han Chinese migrants gravely worsened the situation of most Mongols, as most of the obligations originally requested by local governments to the Han Chinese migrants now fell onto the Mongols. The departure of Han Chinese peasants destroyed another pillar of the frontier governance system. Mongols were now called upon to pay taxes and provide labor for local infrastructural building. ${ }^{50}$ This left the Mongols in direct confrontation with the Han Chinese warlords and their protégées.

To briefly summarize, the warlords' regimes broke apart the frontier governance system that had been carefully put together by frontier military governors during the land reform. By completely subjugating frontier military governors, the warlords' rule damaged the intermediate linkage between the center and periphery, Han and Mongols. No longer discreetly pursuing a middle path of balancing the interests of multiple parties, the warlords were mainly interested in strengthening their local kingdoms. These efforts resulted in regional centralization. In this case, a similar trajectory of minority separatism, like that of the Ottoman and Russian Empires, appeared.

Witnessing the decay of the frontier brokerage system, the Mongols realized a direct confrontation with the Han Chinese warlords' regimes was inevitable. Lacking intermediate forces to moderate the Mongol-Han opposition, conflict became constant and brutal. Unlike one decade previously, Mongols were no longer attracted by the prospect of uniting with Han

\footnotetext{
${ }^{49}$ Ibid., p. 388.

${ }^{50}$ Minguo shinian zhi minguo ershinian kenwu gaikuang (General conditions of land reclamation from 1921 to 1931), collected in Suiyuan tongzhi guan (2007 [vol. 38], p. 359).
} 
Chinese migrants under powerful brokers - the frontier military governors. Instead, they sought alliances with other Mongols against the warlords. In the archives, the first Mongolian petition for establishing an interleague association appeared in 1925, exactly at the same time that Feng Yuxiang solidified his control in Suiyuan. The nobles of the Ulaanchab and Yekhe Juu leagues actively worked on a horizontal Mongolian association that could protect Mongolian interests. Not wanting to incur the suspicions of separatism, they used the rhetoric of "administrative convenience," saying that "the six banners of the Ulaanchab league and the seven banners of the Yekhe Juu league were located at great distances from one another, which created extra obstacles for local administration." ${ }^{51}$ These attempts to form a Mongolian association indicated that Mongol-Han ethnic division was firmly entrenched.

A more far-flung Mongolian separatist movement came into being during the 1930s. It was organized by a prominent Mongol noble from the Shiliyin Gool league, Prince De, in 1933 and attracted a great number of nobles and Mongolian intellectuals. Unlike most nationalist movements that highlighted the goal of establishing independent states (see, e.g., Breuilly 1982, Anderson 1983, Tilly 1997), the Mongolian separatist movement specifically sought to demarcate the boundaries between Mongolian and Han Chinese territories in a swift response to the expansion of Han Chinese warlordism. This crisis of "Mongolian separatism" was exacerbated even more by the spread of Japanese imperialism into north China. ${ }^{52}$

\section{DISCUSSION AND CONCLUSION}

In dialogue with a variety of literature on the center-periphery relationship in empires, this article explains the belated emergence of Mongolian separatism within the context of Chinese imperial dissolution. I focused on three periods, each of which, according to the mainstream center-periphery perspective explanation, was characterized by a set of events that could have spurred Mongolian separatism. The first period was strongly influenced by the deployment of land reform, which was in many aspects analogous to the late imperial reforms adopted by the Ottoman and Russian Empires to strengthen state capacity. Yet unlike the course of events in the other two

\footnotetext{
${ }^{51}$ Petition sent by the Ulaanchab and Yekhe Juu leagues to the Department of Mongolian and Tibetan Affairs regarding the foundation of the Ulaanchab-Yekhe Juu Association (1925, no specific date). It is included in Dazongtong, Mengzangyuan dui ge mengqu youguan difang zhidu zi chen cheng tiao deng gongwen de zhaofu [The president's and the Department of Mongolian and Tibetan Affairs' responses to the Mongolian banners' petitions about local institutions], MZYD, Quanzongjuan 440, anjuanhao 22.

${ }^{52}$ For Prince De's leadership of this movement, see Jagchid (1999) and Atwood (2002). For the relevant original sources, see Tan (1935).
} 
empires, the land reform, though markedly diminishing the authority of the Mongol banners, did not result in Mongolian separatism. My study shows that, in this case, political centralization moved in tandem with the consolidation of an intermediate body - the frontier governance system - in which the frontier military governors acted as powerful brokers who orchestrated the smooth inner workings of this system. Political centralization did not destroy, but rather was facilitated by, the growth of the hinges between center and periphery, Han and Mongols. This layer of intermediate governance largely diffused the pressure of centralization. Mongols were not victimized in this process, so no separatism occurred.

The second period saw the eruption of revolution and the Qing Empire replaced by the Republic of China. Political disorder and sinicization of frontier institutions could have triggered Mongolian separatism. Even so, there was still no separatist movement. My study shows that Mongol nobles and Han Chinese migrant elites were not split by their ethnic differences. Instead they were united by their common interest to in perpetuating the frontier governance system led by the frontier military governors. This system again buffered the Mongolian frontier from the repercussions of a series of dramatic events that could have encouraged Mongolian separatism.

The third period was characterized by the collapse of the central government and the advent of Han Chinese provincial warlordism. While militarily subjugating the frontier to the provincial bases, the warlords instituted their own protégées as frontier military governors. These practices completely destroyed the intermediate body of governance. The hinges between center and periphery, Han and Mongols, vanished with the dissolution of the frontier governance system. Mongols were suddenly under the direct, blatant exploitation of the warlords' regimes, and Mongol-Han confrontations also became acute. At this juncture, Mongolian separatism finally emerged. This third period most coherently evinces the strength of center-periphery explanations that assume political centralization will instigate minority separatism, but at a regional rather than a national level.

The China-Inner Mongolia case therefore shows that specific events alone, such as political centralization, state collapse, nationalization, and so on, can hardly decide the timing and chances of minority separatism for all empires. Instead, the causal effects of these events are more accurately measured by taking into account the confounding mechanism of the structural transformations of the intermediate body of governance. In the ChinaInner Mongolia case, the intermediate body of governance is multiethnic, consisting of both central and local agents, thereby combining characteristics of both direct and indirect rule. This structure challenges the centerperiphery explanation, which assumes a clear-cut dichotomy of direct and indirect rule. Moreover, the China-Inner Mongolia case shows that the causal effects of the transition from indirect to direct rule on minority separatism are 
most conspicuous at a regional level, when the intermediate body of governance evaporated along with the collapse of the central government. In other words, direct confrontation between the Mongols and Han Chinese regimes occurred on a regional rather than a national scale. Based upon these findings, a center-periphery model can be constructed that will take into account the structural determination of intermediate connections linking the center to the periphery and how those connections mediate the effects of events that could potentially split the empire.

Although this study does not explicitly deal with the question of Mongolian nationalism, it does shed important light on that point. Conceiving of nationalism as a force driven by an aspiration toward cultural identity, most previous studies emphasize the joint mobilizing efforts of Mongolian intellectuals and politicians (Bulag 1998; Jagchid 1999). Some perceive Mongolian nationalism to be a contingent outcome of large-power contentions, mainly between China and Russia (Liu 2004). These studies offer detailed accounts of the Mongolian nationalist leadership groups, their ambiguous participation in Chinese communist movements, and their strategic position in the Sino-Russia geopolitical relationship. Yet these scholars fail to address a long-term question: Beginning in the late 19th century, in what sense was Mongolian nationalism correlated with the transformation of the Chinese imperial system? This question leads us beyond a parochial interest in the Chinese minority question and characterizes the China case as a companion to the transition of the Ottoman and Russian Empires. Some scholars have conducted this pioneering work (e.g., Esherick 2006), but their studies are limited by the assumptions of center-periphery explanations. Failing to address the belated timing of Mongolian separatism, they deem revolution and the creation of a Chinese national republic to be decisive events that automatically awakened the Mongolian national consciousness and propelled Mongolian separatism.

In this article, I correct this false periodization. My study shows that the decisive events triggering Mongolian nationalism were not specifically due to external impingements on Inner Mongolia. Rather, they were events that resulted in structural transformations profoundly changing the positions of the Mongols and Han in the local political system, ultimately creating a confrontational relationship between the two groups. Instead of treating state centralization as an exogenous event, or an "ever-present and ever-rising force" (Sewell 2005, p. 90), my study reveals the local structural transformation that facilitates or constrains the unfolding and impact of state centralization. For that reason, the rise of ethnic confrontations in Inner Mongolia is not presented as a variation of the "master process" demonstrating how center impingements trigger peripheral separatism. Instead, this increase in acrimony shows how the convergence or divergence of local transforma- 
tions with impingements from a central point affects the chances of peripheral separatism. ${ }^{53}$

Moreover, inspired by recent ethnic studies (Brubaker 2004; Wimmer 2008) that question the essential nature of ethnicity, my study confirms that ethnic identity is not a predetermined thing, waiting to be awakened. Neither is it a purely intellectual construct (Hobsbawm and Ranger 1992). Instead, collective identity, as revealed in this series of events, is relationally based (Gould 1995). This article tremendously benefits from the localrelational approach employed in macrosociological studies (Bearman 1993; Gould 1995; Barkey and Van Rossem 1997). Not conceiving of macroevents as a transformative power that shape identity, my study is built upon the insight that there are many ways in which people can view their relations with each other (Gould 1995). It is a person's position in these relations that determines at which point which particular identity is prioritized. In both the land reform and the interregnum period after the revolution, Mongols gave priority to their identity as a member of the frontier governance system, as did the Han Chinese migrants, despite their comprehensive dissimilarity in language, customs, culture, and occupations. When the frontier governance system that sustained this identity ruptured during the warlord period, Mongols found themselves in direct confrontation with intrusive Han Chinese regimes. This new position consolidated the notion that Mongols shared nothing in common with Han Chinese and that they must politically unite against the latter. Put another way, the frontier governance system facilitated cross-cutting identities for both Mongols and Han Chinese migrants. Mongols were nomads enrolled in a banner/league system, engaged in a distinct pastoral mode of economic life. Han Chinese migrants were sedentary peasants governed by a bureaucratic system. However, elites from both groups were simultaneously and foremost members of the frontier governance system. These cross-cutting identities dwindled with the rise of the Chinese warlords. The absence of cross-cutting collective identities would lead one to expect very high levels of mobilization, as Gould (1995, p. 17) argues. It is not surprising that Mongolian separatism erupted at the juncture when the frontier governance system that sustained hybridized identities for both Mongols and Han Chinese collapsed.

The dwindling of cross-cutting identities corresponds to the evaporation of the frontier governance system as an intermediate body, in the aftermath of which a polarized center-periphery structure emerged. The Chinese imperial structure is somewhat analogous to the three-layered structure of

\footnotetext{
${ }^{53}$ My study tries to not commit the error as stated by Sewell (1996, p. 102) that "the local variations are mere surface perturbations with no long-term effect on the course of history."
} 
world-systems constructed by Immanuel Wallerstein (1974). The threelayered structure encompasses the center, the periphery, and the semiperiphery and characterizes both world empires and world economies, whose stability specifically hinges on the functioning of the semiperiphery.

In many world empires, the semiperiphery was represented by a middle stratum that participated in the "marginally desirable long-distance luxury trade," and whose economic activities considerably increased the cohesiveness of isolated clusters of local society (Wallerstein 1974, p. 405). The core controlled the military machine that guaranteed its ability to redistribute economic resources in the imperial realm. Careful manipulation of the middle stratum was key to the stability of the empire. On the one hand, the core had to allow the middle stratum to garner some portion of trade benefits so that a potential leadership of local society was bought off by the center. On the other hand, the core had to contain the growth of this stratum by frequently resorting to confiscatory measures, lest the middle stratum overshadow the center. The semiperiphery zones in the world economy played an isomorphic role. Being both the exploited and the exploiter, the semiperiphery largely diffused the tension between the center and the periphery, and thus reduced the possibility of the center being faced with the united opposition of all others (Wallerstein 1974, p. 405).

The frontier governance system analyzed here has a structure akin to the semiperiphery in the world-systems. As I have shown, the demolition of this structure led to polarized confrontations between the newly formed regional political centers and the Mongolian frontier, the Han Chinese warlords, and the Mongol nobles. The polarization of the center-periphery relationship (in the China case, on a regional scale) therefore is an important cause of minority separatism. This key mechanism however is entirely missing from most center-periphery explanations, which presume an initial opposition between the center and the periphery. This initial opposition was not expressly articulated when the center was kept at distance from the periphery (through indirect rule) but became an overtly disruptive force when the distance was shortened (the transition to direct rule). The center-periphery explanations therefore fail to address an initial situation in which the center is not inimical to the periphery, not exactly because of distance, but because of the existence of another layer of relationship that welds the interests of the center and the periphery. In other words, we need to explain rather than assume the polarization of the center-periphery relationship.

Finally, this new focus on the polarization of center-periphery relationship leads us to reflect upon the broader issue of imperial dissolution and minority nationalism in other empires. It would be worthwhile to inquire whether the semiperiphery, in the form of an intermediate body of governance that sustained cross-cutting identities, existed in either the Ottoman Empire or the Russian Empire. If it did exist, how is its transformation re- 
lated to minority nationalism in both countries? Scholars of the Ottoman Empire have long been aware of the intersecting divisions of Ottoman society. Among them, the best-known division was enforced along religious lines, breaking the Ottoman imperial realm into four millets. Respectively, these were the Orthodox Greek, Jewish, Armenian, and Muslim millets. ${ }^{54}$ However, the millet mainly wielded judicial and religious authority, whereas secular administrative authority was attributed to other units such as provinces, cities, rural villages, and so on (see Shaw 1976-77, pp. 150-51; Wimmer 2002, pp. 159-62). These intersecting divisions muddled the boundaries of center and periphery in the Ottoman Empire. To what extent their components were interwoven into an intermediate layer of governance that buttressed the construction of hybridized identities is an interesting question. Answering it will certainly raise new questions about the causes of minority separatism.

The Russian Empire could likewise be divided into intersecting parts. As Edward Walker (2006) argues, Tsarist Russia never relied on "horizontal fraternal feelings" of national belonging to bind the empire as a whole. It was instead built upon the Orthodox principle (religiously) and the autocratic power of the tsar (politically). The discrepancy between the Orthodox and non-Christian religious believers, as well as the status distinction between the nobles and peasants, far exceeded ethnic differences in the Russian Empire. ${ }^{55}$ It is therefore inadequate to conceive of the Russian Empire as constructed in accordance with a strictly defined center-periphery model that assumes the center and the periphery are mainly distinguished by ethnic differences. If these differences were engendered by intersecting rather than compartmentalized political institutions, an extra layer of political relationship might have been generated that would nourish hybridized identities. Whether and under what conditions these hybridized identities lost salience and were replaced by a strong ethnic identity are also interesting questions that would refresh our understanding of minority separatism and the Russian imperial dissolution.

\footnotetext{
${ }^{54}$ The Orthodox Greek millet unified the Bulgarian, Serbian, and Greek patriarchates under the patriarch of Constantinpole. The Jewish millet was led by the grand rabbi of Istanbul and attracted Jewish emigrants from Western Europe, Spain, Portugal, Germany, and Central Europe. The Armenian millet ruled subjects not belonging to other religious groups, e.g., Gypsies, the Assyrians, the Monophysites of Syria and Egypt, the Bogomils of Bosnia, etc. The Muslim millet governed most Muslim populations and greatly expanded after the conquest of the Arabs. See Shaw (1976-77, pp. 151-52).

${ }^{55}$ Walker (2006) argues that only European colonial empires emphasized ethnic distinctions. Slezkine (1994) similarly argues that the superiority of Russians over the Moldavians was felt to be related to education, rather than ethnicity. However, since the 1990s scholars have tended to spread the notion that the Russian empire was a multinational empire. For example, Francine Hirsh (2005) illustrates the continuous production of ethnographical knowledge and using that to frame multinational policy, a practice persisting from imperial Russia to the Soviet Union.
} 
APPENDIX

TABLE A1

Administrative Experiences of the Frontier Military Officials, 1900-1916

\begin{tabular}{|c|c|}
\hline Name & Experiences \\
\hline Yongde & $\begin{array}{l}\text { Chakhar dutong (1880), U-li-ya-su-tai jiangjun in Outer Mongolia } \\
\text { (1901), later committed suicide. }\end{array}$ \\
\hline Xinke & $\begin{array}{l}\text { Miyun deputy dutong around Beijing (1898), Jiangning jiangjun in } \\
\text { Jiangsu (1900). }\end{array}$ \\
\hline Yigu & $\begin{array}{l}\text { Attended the Hanlin yuan (Imperial Academy) after getting the } \\
\text { degree, later worked for Ronglu and acted as vice minister before } \\
\text { being dispatched to Suiyuan. }\end{array}$ \\
\hline Kunxiu & $\begin{array}{l}\text { Vice minister of the Court of Dependencies (1906), official visit to } \\
\text { Germany, U-li-ya-su-tai jiangjun (1908). }\end{array}$ \\
\hline Xiliang & $\begin{array}{l}\text { Pingyang prefect in Shanxi (1893), Yizhou prefect in Shandong (1895), } \\
\text { provincial surveillance commissioner in Shanxi (1898), provincial } \\
\text { administrative commissioner in Hunan (1899), governor of Shanxi } \\
\text { (1900), governor of Henan (1901), Sichuan governor-general (1903), } \\
\text { governor-general of Yunnan and Guizhou (1907), governor-general } \\
\text { of the three northeastern provinces (1909) }\end{array}$ \\
\hline
\end{tabular}

Tingjie . . . . . . Chengde prefect in Zhili (1876), circuit intendant in Hunan (1890), Fengtian prefect (1897), provincial administrative commissioner in Zhili (1898), Shengjing jiangjun (1905).

Kuishun . . . . . . X. Xining banshi dacheng (1891), U-li-ya-su-tai jiangjun (1904).

Songshou . . . . . Henan governor (1900), minister of works (1902), vice minister of war (1905), later also Fujian governor.

Zhang Shaozeng ... Staff officer for Zhang Huaizhi (1903), artillery regiment commander of the 2d Division, director of the training office in Zhili and director of the Imperial Military School before the revolution, commander of the 20th Division in northeast (1911), Shanxi governor (1912).

Pan Juying . . . . Regiment commander in the 20th Division in Zhili (1907), commander of the 20th Division (1911).

Jiang Yanxing .... Brigade commander of the 13th Brigade in Jiangsu before 1911 and after that the Jiangsu governor, military commissioner of Jiangbei stationed in Jiangsu (1913).

He Zonglian ... . . Director of the Beiyang No. 1 Training Office (1904), battalion officer in the 1st Brigade in Gansu (1906), commander of the 1st Division stationed in Gansu, deputy Chakhar dutong (1907).

Zhang Huaizhi .. . Commander of the 5th Division stationed in Shandong (1909), provincial military commander in Gansu (1911), regional commander in Tianjin (1911), commander of the Patrol Defense Corps in Shandong (1912), governor in Anhui (1912).

Tian Zhongyu .... B Brigade commander of 4 th Brigade in the $2 \mathrm{~d}$ Division stationed in Zhili (1904), brigade commander of the Mixed Brigade of New Army in Guangdong (1906), major advisor in the Training Office of the three northeastern provinces (1907), brigade commander of the 23d Mixed Brigade of the New Army in Jiangsu (1910), regional commander in Yanzhou in Shandong (1911), commander of Military Defense Army in Shandong (1912), vice minister of war in Beijing (1915), military governor in Jilin (1916).

Xiong Xiling .... Studied in Japan (1900), teaching in Changde Normal School (1903), accompanying five ministers studying constitution abroad (1905), director of Agriculture, Industry, and Commerce in Fengtian (1906), commissioner of salt transportation in Fengtian (1910), financial secretary in Jiangsu (1911), minister of finance (1912). 
TABLE A1 (Continued)

\begin{tabular}{lr}
\hline \hline Name & \multicolumn{1}{c}{ Experiences } \\
\hline Jiang Guiti ...... & $\begin{array}{l}\text { Joined Seng-ge-lin-qin's army to suppress the Nian rebellion in north } \\
\text { China (1865) and later joined Zuo Zongtang to suppress the Muslim } \\
\text { rebellion in Gansu, brigade commander in Yunan and joined Song } \\
\text { Qin's Yi Army (1894), regiment commander in Yuan Shikai's New } \\
\text { Army (1896), provincial military commander (1900), chief commander } \\
\text { of the wuwei youjun stationed in Beijing (1901), Zhili military } \\
\text { commander and the chief commander of wuwei zuojun (1908). }\end{array}$ \\
\hline
\end{tabular}

Note.-The sources of data are Manzu da cidian (Manchu Dictionary; Sun et al. 1990), Biographies Related to the Qing History (Guoshiguan and Zhonghua shu ju 1928), and Dictionary of People during the Republic of China (Xu 2007).

TABLE A2

Administrative Experiences of the Frontier Military Officials, 1917-28

\begin{tabular}{|c|c|}
\hline Name & Administrative Experience \\
\hline ang Yanxing & $\begin{array}{l}\text { Commander of the 13th Brigade stationed in Jiangsu before 1911, } \\
\text { commissioner of military defense in north Jiangsu (1913). }\end{array}$ \\
\hline Chen Guangyuan & $\begin{array}{l}\text { Commander of the } 7 \text { th Brigade of the 4th Division stationed in } \\
\text { Tianjin (1910), commander of the 4th Division in Tianjin (1911), } \\
\text { private consultant for Yuan Shikai in Beijing (1912), commander } \\
\text { of Military Patrol Corps in Jehol (1913). }\end{array}$ \\
\hline Cai Chengxun & $\begin{array}{l}\text { Deputy commander of the army stationed in Beijing (1900), brigade } \\
\text { commander in the 21st Division stationed in Zhejiang (1911), } \\
\text { commander of the military guards for Yuan Shikai (1912), com- } \\
\text { mander of the 1st Brigade of the 1st Division (1913), commander of } \\
\text { the 1st Division (1914), commander of the 7th Army corps (1917). }\end{array}$ \\
\hline Ma Fuxiang & $\begin{array}{l}\text { Joined the Gansu army led by Dong Fuxiang (1898), Altai military } \\
\text { commissioner (1904), brigade commander of Gansu and Ningxia } \\
\text { (1912). }\end{array}$ \\
\hline Li Mingzhong & $\begin{array}{l}\text { Regiment commander (1917), brigade commander (1921), brigade } \\
\text { commander of the } 21 \text { st Brigade of the 11th Division stationed in } \\
\text { Henan (1922), commander of the } 8 \text { th Mixed Brigade (1924), } \\
\text { commander of the 6th Division of the 1st Army Corps led by Feng } \\
\text { Yuxiang (1924). }\end{array}$ \\
\hline Liu Yufen & $\begin{array}{l}\text { Platoon officer in the 19th Division stationed in Yunnan before the } \\
\text { revolution, teaching in military school of Beijing (1912), teaching } \\
\text { officer in the 16th mixed brigade of Feng Yuxiang's army (1912), } \\
\text { chief of staff of the 16th Mixed Brigade (1914), commander of the } \\
\text { 20th Brigade (after second Zhili-Fengtian War), Gansu military } \\
\text { governor under Feng's leadership (1924). }\end{array}$ \\
\hline Jiang Hongyu & $\begin{array}{l}\text { Teaching officer and staff officer of the 26th Mixed Brigade in Feng } \\
\text { Yuxiang's army, commander of the 12th Division (1925). }\end{array}$ \\
\hline Song Zheyuan & $\begin{array}{l}\text { Attended Feng Yuxiang's battalion in Lu Jianzhang's army (1912), } \\
\text { deputy commander of the 1st Battalion of the 16th Mixed Brigade } \\
\text { (1914), commander of the 1st Battalion (1917), commander of the } \\
\text { 25th Mixed Brigade (1922), commander of the 11th Division (1924). }\end{array}$ \\
\hline Shang Zhen .. & $\begin{array}{l}\text { Joined the new army in northeast before the revolution, dispatched } \\
\text { to Shaanxi with Shaanxi governor Lu Jianzhang and acted as } \\
\text { battalion commander (after 1912), commander of the 1st Regiment } \\
\text { in Shaanxi(1915), commander of the 4th Mixed Regiment in Shanxi }\end{array}$ \\
\hline
\end{tabular}


TABLE A2 (Continued)

\begin{tabular}{|c|c|}
\hline Name & Administrative Experience \\
\hline & $\begin{array}{l}\text { (1915) and joined Yan Xishan's army, commander of the 1st } \\
\text { Division in south Shanxi (1924). }\end{array}$ \\
\hline Mantai & $\begin{array}{l}\text { Active revolutionary member in Suiyuan, commander of the } 1 \text { st } \\
\text { Brigade of the Suiyuan calvary (1926). }\end{array}$ \\
\hline Guo Xipeng & $\begin{array}{l}\text { Platoon commander in the } 27 \text { th division in northeast before he went } \\
\text { to Japan in 1923, commander of the } 2 \text { d Regiment of the 8th } \\
\text { Calvary Brigade in northeast (1925), Commander of the 8th } \\
\text { Calvary Brigade (1926), commander of the 16th Division (1927). }\end{array}$ \\
\hline Ji Jinchun & $\begin{array}{l}\text { Bandit in his early years and after being pacified joined the Fengtian } \\
\text { army, commander of the 56th Brigade of the 28th Division (1913), } \\
\text { commander of the 28th Division (1917), Jehol dutong (1921), } \\
\text { deputy commander of the 4th Army Corps and the commander of } \\
\text { the 9th Division in Fengtian army (1924). }\end{array}$ \\
\hline Zhang Jingyao & $\begin{array}{l}\text { Joined Yuan Shikai's New Army (1896), battalion commander of the } \\
\text { 6th Division, commander of the 3d Mixed Regiment (1914), } \\
\text { participated the war in Sichuan and worked for the military } \\
\text { defense in Sichuan (1916), commander of bandit-exterminating } \\
\text { force in four provinces (Jiangsu, Anhui, Shandong, and Henan) } \\
\text { under Duan Qirui's leadership (1917). }\end{array}$ \\
\hline Wang Tingzhen .... & $\begin{array}{l}\text { Regiment officer in Qing army (1903), commander of Imperial } \\
\text { Military Guards (1909), commissioner of military defense in } \\
\text { Tianjin (1913), commissioner of military defense in Jiangsu (1914), } \\
\text { inspector general of Jiangsu (1917). }\end{array}$ \\
\hline Zhang Jinhui & $\begin{array}{l}\text { Battalion commander in the Patrol Defense Corps of Fengtian led } \\
\text { by Zhang Zuolin before the revolution, various military positions } \\
\text { in Fengtian army until promoted to the commander of the 1st } \\
\text { Division (1912-1918), commander of the 16th Division (1920). }\end{array}$ \\
\hline Zhang Xiyuan ..... & $\begin{array}{l}\text { Commander of the 58th Regiment of the 29th Mixed Brigade in } \\
\text { Henan (1911), commander of the 1st Division in Henan (1912), } \\
\text { commander of the 9th Division (1914), commander of the 2d } \\
\text { Regiment in Beijing (1916), attended war in Shaanxi (1918) and } \\
\text { the commissioner of military defense in Shaanxi (1921), later } \\
\text { joined Feng Yuxiang's army. }\end{array}$ \\
\hline Zhang Zhijiang & $\begin{array}{l}\text { Joined the Tianjin army (1903), platoon commander of the 1st Mixed } \\
\text { Brigade in Fengtian (1907), organized the Study Group of Martial } \\
\text { Arts with Feng Yuxiang (1910), secondary staff officer of the } \\
\text { Eastern Route of North Shanxi army (1912), staff officer of the } \\
\text { 16th Mixed Brigade led by Feng Yuxiang (1914), regiment } \\
\text { commander of the 16th Mixed Brigade (1918), commander of the } \\
\text { 22d Brigade of the 11th Division in Shaanxi. }\end{array}$ \\
\hline Lu Zhonglin & $\begin{array}{l}\text { Joined the 6th Division in Beijing (1907), official in the 79th Regiment } \\
\text { of the 40th Brigade (1910), joined the northern revolutionary army } \\
\text { but failed (1912),various positions in the 16th Mixed Brigade led by } \\
\text { Feng Yuxiang (1916-21), chief of the Department of Police in } \\
\text { Henan (1922), garrison commander in Beijing (1924). }\end{array}$ \\
\hline Gao Weiyue & $\begin{array}{l}\text { Chief of staff in the } 27 \text { th Division (1912), commander of the 53d } \\
\text { Brigade (1921), commander of the } 7 \text { th Division of the Northeastern } \\
\text { army (1925), commander of the 9th Corps Army of Anguojun led } \\
\text { by Zhang Zuolin (1926). }\end{array}$ \\
\hline Zhao Daiwen & $\begin{array}{l}\text { President of Shanxi University (1900). Joined Yan Xishan and } \\
\text { appointed as the chief of the Department of Secretary in Shanxi } \\
\text { provincial government (1912), chief of staff in Shanxi provincial } \\
\text { army (1916), commander of the 4th Mixed Brigade (1917), joined } \\
\text { the Nationalist party and led the Shanxi party branch (1926). }\end{array}$ \\
\hline
\end{tabular}




\section{From Masterly Brokers to Compliant Protégées}

TABLE A2 (Continued)

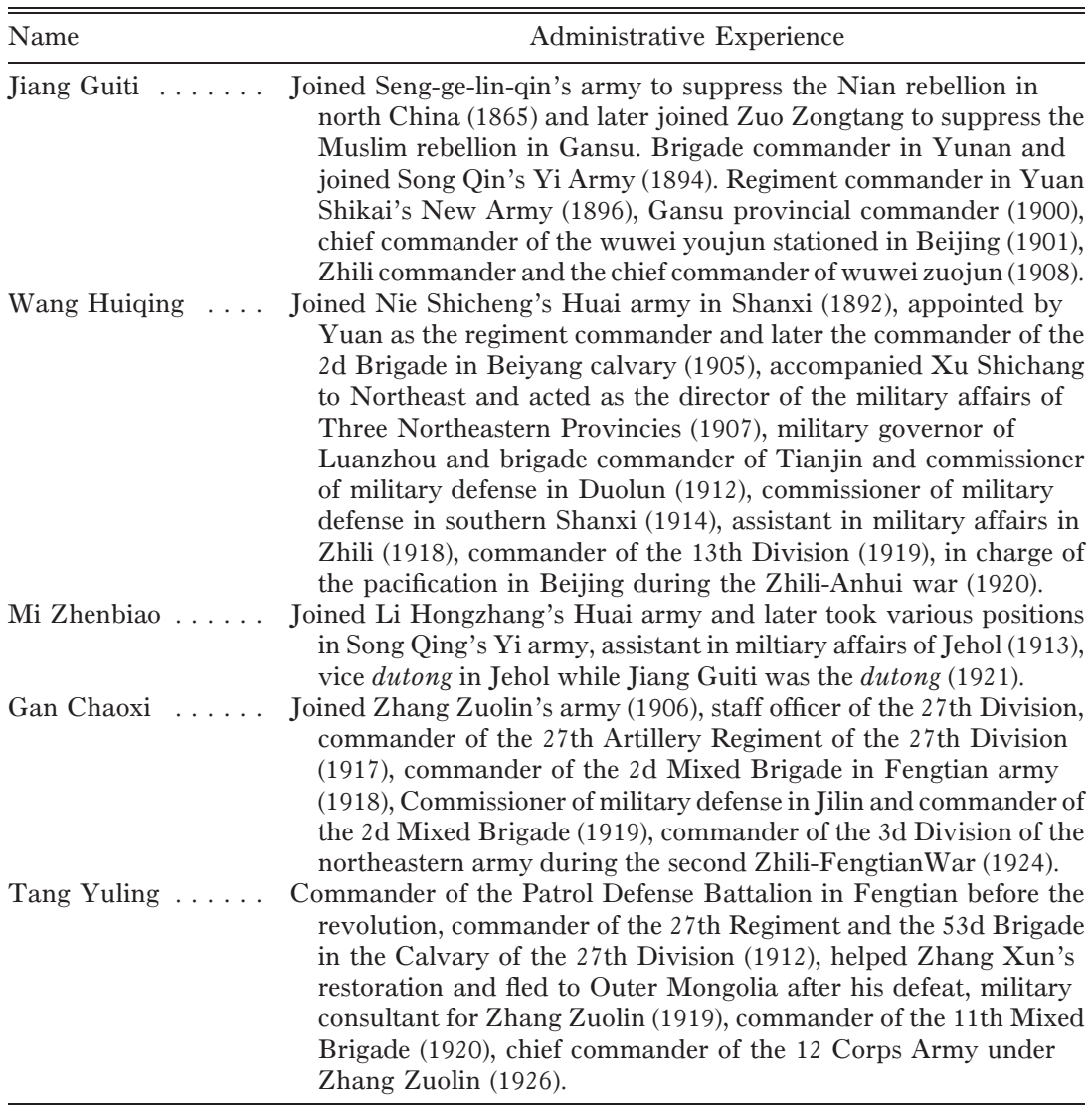

Note.- The source of these data is the Dictionary of People during the Republic of China (Xu 2007).

\section{REFERENCES}

Aberle, David F., and Herbert Vreeland. 1962. Chahar and Dagor Mongol Bureaucratic Administration: 1912-1945. New Haven, Conn.: HRAF Press.

Adams, Julia, and George Steinmetz. 2015. "Sovereignty and Sociology: From State Theory to Theories of Empire." Political Power and Social Theory 28:269-85.

Anderson, Benedict. 1983. Imagined Communities: Reflections on the Origin and Spread of Nationalism. London: Verso.

Armitage, David. 2000. The Ideological Origins of the British Empire. New York: Cambridge University Press.

Atwood, Christopher Pratt. 2002. Young Mongols and Vigilantes in Inner Mongolia's Interregnum Decades, 1911-1931. Boston: Brill.

Baoyu. "Qingmo Suiyuan kenwu" [Land reclamation in Suiyuan in late Qing]. 1985. Pp. 33-216 in Neimenggu shizhi ziliao huibian [Historical materials of Inner Mongolia], compiled by Neimenggu difangzhi bianzuan weiyuanhui. 
Barkey, Karen. 1994. Bandits and Bureaucrats: The Ottoman Route to State Centralization. Ithaca, N.Y.: Cornell University Press.

. 2006. "Changing Modalities of Empire: A Comparative Study of Ottoman and Habsburg Decline." Pp. 167-98 in Empire to Nation, edited by Joseph Esherick, Hasan Kayah, and Eric Young. New York: Rowman \& Littlefield.

- 2008. Empire of Difference: The Ottomans in Comparative Perspective. New York: Cambridge University Press.

Barkey, Karen, and Robert van Rossem. 1997. "Networks of Contention: Villages and Regional Structure in the Seventeenth-Century Ottoman Empire." American Journal of Sociology 102 (5): 1345-82.

Bartlett, Robert. 1993. The Making of Europe: Conquest, Colonization, and Cultural Change, 950-1350. Princeton, N.J.: Princeton University Press.

Bearman, Peter. 1993. Relations into Rhetorics: Local Elite Social Structure in Norfolk, England, 1540-1640. New Brunswick, N.J.: Rutgers University Press.

Beik, William. 1985. Absolutism and Society in Seventeenth-Century France: State Power and Provincial Aristocracy in Languedoc. New York: Cambridge University Press.

Beissinger, Mark R. 2002. Nationalist Mobilization and the Collapse of the Soviet State. New York: Cambridge University Press.

Boldbaatar, J., and David Sneath. 2006. "Ordering Subjects: Mongolian Civil and Military Administration." Pp. 293-314 in Imperial Statecraft: Political Forms and Techniques of Governance in Inner Asia, Sixth to Twentieth Centuries, edited by David Sneath. Bellingham, Wash.: East Asian Studies Press.

Breuilly, John. 1982. Nationalism and the State. Chicago: University of Chicago Press.

Brubaker, Rogers. 1994. "Nationhood and the National Question in the Soviet Union and Post-Soviet Eurasia: An Institutionalist Account." Theorv and Societv 23 (1): 4778.

2004. Ethnicity without Groups. Cambridge, Mass.: Harvard University Press.

Brunnert, İppolīt Semenovīch, V. V. Hagelstrom, Nī Kolesov, Andrei Terent'evich Biel'chenko, and Edward Eugene Moran. 1911. Present Day Political Organization of China. New York: Paragon.

Bulag, Uradyn Erden. 1998. Nationalism and Hybridity in Mongolia. New York: Oxford University Press.

Campbell, Elena. 2007. "The Muslim Question in Late Imperial Russia.” Pp. 320-48 in Russian Empire: Space, People, Power, 1700-1930, edited by Jane Burbank, Mark von Hagen, and Anatolyi Remnev. Bloomington: Indiana University Press.

Chi, His-sheng. 1976. Warlord Politics in China, 1916-1928. Stanford, Calif.: Stanford University Press.

Comisso, Ellen. 2006. "Empire as Prisons of Nations versus Empires as Political Opportunity Structures: An Exploration of the Role of Nationalism in Imperial Dissolutions in Europe." Pp. 138-67 in Empire to Nation: Historical Perspectives on the Making of the Modern World, edited by Joseph Esherick, Hasan Kayah, and Eric Van Young. New York: Rowman \& Littlefield.

Cooper, Frederick. 1997. "The Dialectics of Decolonization: Nationalism and Labor Movements in Post-War French Africa." Pp. 406-636 in Tensions of Empire: Colonial Cultures in a Bourgeois World, edited by Frederick Cooper and Ann Laura Stoler. Berkeley and Los Angeles: University of California Press.

Crossley, Pamela. 2005. "Nationality and Difference in China: The Post-Imperial Dilemma," Pp. 138-58 in The Teleology of the Modern Nation-State: Japan and China, edited by Joshua A. Fogel. Philadelphia: University of Pennsylvania Press.

Davison, Roderic. 1977. "Nationalism as an Ottoman Problem and the Ottoman Response." Pp. 25-57 in Nationalism in a Non-National State: The Dissolution of the Ottoman Empire, edited by William W. Haddad and William Ochsenwald. Columbus: Ohio State University Press. 
Doyle, Michael W. 1986. Empires. Ithaca, N.Y.: Cornell University Press.

Duara, Parasenjit. 1988. Culture, Power and the State: Rural North China, 1900-1942. Stanford, Calif.: Stanford University Press.

Esherick, Joseph. 2006. "How the Qing Became China." Pp. 229-59 in Empire to Nation: Historical Perspectives on the Making of the Modern World, edited by Joseph Esherick, Hasan Kayah, and Eric Van Young. New York: Rowman \& Littlefield.

Friskesjo, Magnus. 2006. "Rescuing the Empire: Chinese Nation-building in the Twentieth Century." European Journal of East Asian Studies 5 (1): 15-44.

Gillin, Donald G. 1967. Warlord: Yen Hsi-shan in Shansi Province, 1911-1949. Princeton, N.J.: Princeton University Press.

Go, Julian. 2009. "The New Sociology of Empire and Colonialism." Sociology Compass $3: 1-14$.

Gould, Roger V. 1995. Insurgent Identities: Class, Community, and Protest in Paris from 1848 to the Commune. Chicago: University of Chicago Press.

Guoshiguan and Zhonghua shu ju. 1928. Qing shi lie zhuan [Biographies related to the Qing history]. Shanghai: Zhonghua shu ju.

Haddad, William W. 1977. "Nationalism in the Ottoman Empire." Pp. 3-25 in Nationalism in a Non-National State: The Dissolution of the Ottoman Empire, edited by William W. Haddad and William Ochsenwald. Columbus: Ohio State University Press.

Von Hagen, Mark. 1997. "The Russian Empire." Pp. 58-73 in After Empire, edited by Karen Barkey and Mark von Hagen. Denver, Colo.: Westview Press.

Hechter, Michael. 2000. Containing Nationalism. New York: Oxford University Press.

Hechter, Michael, Tuna Kuyucu, and Audrey Sacks. 2006. "Nationalism and Direct Rule." Chap. 8 in Handbook of Nations and Nationalism, edited by Gerard Delanty and Krishan Kumar. Thousand Oaks, Calif.: Sage Publications.

Hirsch, Francine. 2005. Empire of Nations : Ethnographic Knowledge and the Making of the Soviet Union. Ithaca, N.Y.: Cornell University Press.

Hobsbawm, Eric, and Terence Ranger. 1992. The Invention of Tradition. Cambridge: Cambridge University Press.

Horowitz, Donald L. 1985. Ethnic Groups in Conflict. Berkeley and Los Angeles: University of California Press.

Hucker, Charles O. 1995. A Dictionary of Official Titles in Imperial China. Stanford, Calif.: Stanford University Press.

Ichiko, Chuzo. 1980. "Political and Institutional Reform, 1901-1911." Pp. 375-411 in The Cambridge History of China, vol. 11. Edited by John King Fairbank and Denis Crispin Twitchett. New York: Cambridge University Press.

Jagchid, Sechin. 1999. The Last Mongol Prince: The Life and Times of Demchugdongrob, 1902-1966. Bellingham: Center for East Asian Studies, Western Washington University.

Jiang, Tiesheng, ed. 2003. Feng Yuxiang nianpu [Chronicle of Feng Yuxiang]. Jinan: Qilu shushe.

Keyder, Caglar. 1997. "The Ottoman Empire." Pp. 30-45 in After Empire, edited by Karen Barkey and Mark von Hagen. Boulder, Colo.: Westview Press.

Kettering, Sharon. 1986. Patrons, Brokers, and Clients in Seventeenth-century France. New York: Oxford University Press.

Khalidi, Rashid. 1977. "Arab Nationalism in Syria: The Formative Years, 1908-1914." Pp. 207-39 in Nationalism in a Non-National State: The Dissolution of the Ottoman Empire, edited by William W. Haddad and William Ochsenwald. Columbus: Ohio State University Press.

Kumar, Krishan. 2010. "Nation States as Empires, Empires as Nation States: Two Principles, One Practice?" Theorv and Societv 29 (1): 119-43.

Lachmann, Richard, and Julia Adams. 1988. "Absolutism's Antinomies: Class Formation, State Fiscal Structures and the Origins of the French Revolution." Political Power and Social Theory 7:135-75. 


\section{American Journal of Sociology}

Lattimore, Owen. 1940. Inner Asian Frontiers of China. New York: American Geographical Society.

Lenin, Vladimir Ilyich. (1914) 1995. "The Right of Nations to Self-Determination." Pp. 208-16 in The Nationalism Reader, edited by Omar Dahbour and Micheline R. Ishay. Atlantic Highlands, N.J.: Humanities Press.

Li Keren. 1990. "Qingdai Wulanchabu Kenwu Chutan” [A preliminary investigation of the land cultivation in Ulaanchab under the Qing]. Pp. 128-40 in Neimenggu Kenwu Yanjiu [Studies on the Land Cultivation in Inner Mongolia]. Hohhot: Neimenggu renmin chubanshe.

Liu, Xiaoyuan. 2004. Frontier Passages: Frontier Politics and the Rise of Chinese Communism, 1921-1945. Washington, D.C.: Woodrow Wilson Center Press.

Lugard, F. D. [Frederick Dealtry]. 1965. The Dual Mandate in British Tropical Africa. Hamden, Conn.: Archon Books.

MacKinnon, Stephen R. 1980. Power and Politics in Late Imperial China: Yuan Shi-kai in Beijing and Tianjin, 1901-1908. Berkeley and Los Angeles: University of California Press.

Mamdani, Mahmood. 1996. Citizen and Subject: Contemporary Africa and the Legacy of Late Colonialism. Princeton, N.J.: Princeton University Press.

Martin, Terry. 2001. The Affirmative Action Empire: Nations and Nationalism in the Soviet Union, 1923-1939. Ithaca, N.Y.: Cornell University Press.

McCormack, Gavan. 1977. Chang Tso-lin in Northeast China, 1911-1928: China, Japan, and the Manchurian Idea. Stanford, Calif.: Stanford University Press.

Neimenggu tushuguan. 2008. Neimenggu lishi wenxian congshu zhi si [Series of historical sources of Inner Mongolia, no. 4]. Hohhot: Yuanfang chuban she.

Motyl, Alexander J. 2001. Imperial Ends: The Decay, Collapse, and Revival of Empires. New York: Columbia University Press.

Perdue, Peter. 2005. China Marches West: The Qing Conquest of Central Eurasia. Cambridge, Mass.: Belknap Press of Harvard University Press.

Posner, Daniel N. 2005. Institutions and Ethnic Politics in Africa. New York: Cambridge University Press.

Qingshi bianwei hui. 1984. Qingdai Renwu Zhuangao [The biographical drafts of people in the Qing]. Beijing: Zhonghua Shuju.

Riga, Liliana. 2008. "The Ethnic Roots of Class Universalism: Rethinking the 'Russian' Revolutionary Elite.” American Journal of Sociology 114 (3): 649-705.

. 2012. The Bolsheviks and the Russian Empire. Cambridge: Cambridge University Press.

Salzmann, Ariel. 1993. "An Ancien Régime Revisited: 'Privatization' and Political Economy in the Eighteenth-Century Ottoman Empire." Politics and Society 21:393423.

Sewell, William. 2005. Logics of History: Social Theory and Social Transformation. Chicago: University of Chicago Press.

Shaw, Stanford J. 1976-77. History of the Ottoman Empire and Modern Turkey. New York: Cambridge University Press.

Sheridan, James E. 1966. Chinese Warlord : The Career of Feng Yü-hsiang. Stanford, Calif.: Stanford University Press.

Skinner, G. W. 1977. The City in Late Imperial China. Taipei: SMC Publishing.

Slezkine, Yuri. 1994. "The USSR as a Communal Apartment, or How a Socialist State Promoted Ethnic Particularism." Slavic Review 53 (2): 414-52.

Su-de-bi-li-ge. 2007. Minguo Neimenggu shi [Republican history of Inner Mongolia]. Hohhot: Neimenggu daxue chuban she.

Suiyuan tongzhi guan. 2007. Suiyuan tong zhi gao [Suiyuan gazetteer]. Hohhot: Neimenggu renmin chuban she.

Sun, Wenliang, Wanquan Liu and Zhiting Li. 1990. Manzu da cidian [Manchu dictionary]. Shenyang: Liaoning daxue chu banshe 
Suny, Ronald Grigor. 1993. Revenge of the Past: Nationalism, Revolution, and the Collapse of the Soviet Union. Stanford, Calif.: Stanford University Press.

Tan, Tiwu. 1935. Neimeng zhi jin xi [Present and past of Inner Mongolia]. Shanghai: Shangwu yinshu guan.

Tighe, Justin. 2005. Constructing Suiyuan: The Politics of Northwestern Territory and Development in Early Twentieth-Century China. Boston: Brill.

Tilly, Charles. 1997. "How Empires End." Pp.1-12 in After Empire, edited by Karen Barkey and Mark von Hagen. Denver, Colo.: Westview Press.

Walker, Edward. 2006. "The Long Road from Empire: Legacies of Nation Building in the Soviet Successor States." Pp. 298-339 in Empire to Nation: Historical Perspectives on the Making of the Modern World, edited by Joseph Esherick, Hasan Kayah, and Eric Van Young. New York: Rowman \& Littlefield.

Wallerstein, Immanuel. 1974. "The Rise and Future Demise of the World Capitalist System." Comparative Studies in Societv and Historv 16:398-415.

Wang, Desheng. 1987. "Beiyang Junfa Duimeng Zhengce Jige Wendi de Chuxi" [A preliminary analysis of the northern warlords' Mongolian policy]. Pp. 26-136 in Neimenggu Jinxiandaishi Luncong, vol. 3. Hohhot: Neimenggu Renmin Chubanshe.

Wang, Liping. 2014. "State, Relational Governance and Nomads' Sedentarization: Land Reform in Inner Mongolia, 1900-1911." Comparative Studies in Society and History 56 (3): 714-44.

Wilson, Nicholas Hoover. 2011. "From Reflection to Refraction: State Administration in British India, circa 1770-1855." American Journal of Sociology 116:1437-77.

Wimmer, Andreas. 2002. Nationalist Exclusion and Ethnic Conflict: Shadows of Modernity. New York: Cambridge University Press.

_. 2008. "The Making and Unmaking of Ethnic Boundaries: A Multilevel Process Theory." American Journal of Sociologv 113 (4): 970-1022.

Xiliang. 1959. Xiliang yi gao (zou gao) [Memorials left by Xiliang]. Zhongguo jindai shi ziliao congshu. Beijing: Zhonghua shuju.

Xu, Youchun. 2007. Minguo renwu da cidian [Dictionary of People in the Republic]. Shijiazhuang: Hebei renmin chubanshe.

Yan Bochuan xiansheng jinian hui. 1988. Minguo Yan Bochuan xiansheng Xishan nianpu [Chronicle of Yan Xishan]. Taibei: Shangwu yinshu guan.

Yigu. 1974. Suiyuan zouyi [Memorials sent from Suiyuan]. Jindai zhongguo shiliao congkan xubian 103. Taibei: Wenhai chuban she.

Young, Crawford. 1965. Politics in the Congo: Decolonization and Independence. Princeton, N.J.: Princeton University Press.

Zhang, Xiamin. 1984. Wang Tongchun yu Suiyuan Hetao zhi Kaifa [Wang Tongchun and development in Suiyuan Hetao]. Taipei: Shangwu.

Zhao, Yuntian. 1989. Qingdai Menggu zhengjiao zhidu. Beijing: Zhonghua shuju. 1993. Zhongguo bianjiang minzu guanli jigou yange shi. Beijing: Zhongguo shehui kexue chuban she.

\section{Correction}

This article was corrected on July 30, 2015, to incorporate missing text in the acknowledgment note on page 1641. An erratum appears in the printed copy of the July 2015 issue (vol. 121, no. 1) of the American Journal of Sociology. 


\section{Erratum}

A proofreading mistake resulted in the publication of an incomplete acknowledgment note for "From Masterly Brokers to Compliant Protégées: The Frontier Governance System and the Rise of Ethnic Confrontation in China-Inner Mongolia, 1900-1930" (120 [6]: 1641-89) by Liping Wang. The complete, corrected note appears below. AJS regrets the error.

The author wishes to thank Julia Adams, Sida Liu, Peter Perdue, Geng Tian, Xiaohong Xu, Nick Wilson, and Dingxin Zhao for their helpful comments on early drafts of this article. She also thanks Mark Gould for his helpful comments on the final revision and the AJS reviewers for their feedback, which made a significant improvement possible. The author is of course responsible for any errors. Direct correspondence to Liping Wang, Social Sciences Collegiate Division, University of Chicago, 5845 South Ellis Avenue, Chicago, Illinois 60637. E-mail: lipingw @uchicago.edu 